\title{
Statistical Appendix
}

Calibrating economic development involves more than compiling data and constructing variables from the assembled figures. Interpretation is as important as estimation. Statistics are only meaningful when they contribute to an argument, a story, advanced by their user. It is essential to keep this point in mind in studying the text and tables assembled in this appendix.

There are three major approaches to calibrate economic development for a country or region: (1) estimating the flow of goods and services generated by the economy, then putting the resulting numbers on a per capita basis by dividing by estimates of population (the income per capita or output per capita approach arrived at through national income accounting); (2) estimating a mix of the capabilities and abilities for the average individual in the population by combining figures on per capita income, life expectancy and educational attainment into a summary measure (the human development approach); and (3) estimating a set of demographic and anthropometric characteristics of the population, particularly concentrating on young persons still growing (e.g., life expectancy, the infant mortality rate, height, weight, chest girth, muscular capacity; the term "biological standard of living" is often used to describe the standard of living as measured through the agency of the anthropometric measures). Most economists and the World Bank in particular favor the income 
per capita approach; the United Nations Development Programme favors the human development approach; and the World Health Organization recommends using anthropometric measures like height and weight for growing children.

From an economist's perspective the income per capita approach has much to recommend it. ${ }^{1}$ Summary measures of total marketed output (in principle equal to total income received by the factors of production) are useful in and of themselves. In addition they can be decomposed: into sector estimates on the supply side (agriculture, fishing, and forestry adding up to primary production; mining and manufacturing constituting secondary or industrial production; and services the tertiary sector); into the components of aggregate demand - consumption, investment, government spending, imports, and exports - on the demand side.

Moreover, growth rates for overall income or income per capita can be generated by computing income levels in different years in so-called constant prices (known as "real income" as opposed to "nominal income"). Finally comparisons between different regions or countries in terms of income or income per capita can be generated by coming up with a common set of prices for the various regions or countries involved, deflating the nominal figures for income generated in the various regions or countries by the purchasing power parity - the actual buying power in terms of securing a specific bundle of goods and services - of the currencies for the various jurisdictions involved. In theory the income approach is compelling because it allows for the calibration of levels of income and income per capita as well as growth rates for income and income per capita.

In practice finding a common set of prices for evaluating the growth of income within a country is difficult. No perfect solution exists. Consider a time series of nominal income figures, prices and volumes being known. Whether one uses prices for the base period in the series or the final period in the series matters in making the actual calculation. This is known as the index number problem. Even more challenging is estimating purchasing power parity of currencies, official exchange rates being a poor proxy as exchange rates tend to reflect the prices of traded goods - most goods and services are not traded - and central bank policies of countries. ${ }^{2}$

Problems encountered in estimation aside, income and income per capita estimates are ubiquitous in the empirical economic development literature. Most of the tables in this Appendix - Tables A.2-A.5 and A.10 make use of them. Estimates of the human development index, life expectancy, infant mortality, and the biological standard of living appear 
in Table A.6. From the point of view of this study the human development index and the biological standard of living are useful supplements to the income per capita measures - and do capture important aspects of human capabilities important to understanding the determinants of the efficiency of an hour worked - but are best used to supplement the income per capita estimates. ${ }^{3}$

Table A.1 provides a basic growth accounting framework used throughout this study. It is discussed in the Appendix to Chap. 2, Sec. 2.6. Please note that the notation, the symbols used for variable names, employed in this table differs somewhat from that utilized in Chaps. 2 and 3. A key feature of the table is the analysis of augmentation in the three factors of production. Note the list of factors that contribute to total factor productivity growth: scale economies, structural change (particularly important is transferring workers from agriculture to industry), and technological and organizational change. This list is important because it points toward the interaction of augmentation and capital accumulation with total factor productivity growth, supporting the argument that the dichotomy between total factor productivity growth and accumulation either of capital and/or accumulation of labor, when combined to make total factor accumulation, is false. Examples supporting the interaction of augmentation of labor and technological progress appear in Chap. 5 (the example of the reverse engineering project of the Japan National Railroads (where the existence of a supply of well trained engineers was crucial) and in Chap. 9 where it is pointed out that the upgrading of educational attainment for blue collar workers imparted a major push to the effective application of "zero defect" and quality control circle principles in the Japanese automobile industry. Another illustration of this principle is the buildup of physical infrastructure - paved road networks, hydro-electrical systems, railroads, container ports and dredged harbors - generating geographic scale economies especially in metropolises. Again consider the following proposition: without physical investment in plant and equipment in manufacturing can structural change, namely the transfer of workers from farming to industry, take place?

Historical estimates of levels of income per capita and population and growth rates for income per capita and population appear in Table A.2. Noteworthy points established by the table are: (1) the existence of Malthusian constraints on growth in per capita income and population prior to the industrial revolution of the 18th century that set the stage for the refinement and diffusion of the inorganic economy; (2) the existence of the great divergence; and (3) the existence of a fundamental shift in the 
Table A.1: Growth accounting equation and the aggregate production function.

From the basic multiplicative aggregate Cobb-Douglas Production Function that assumes constant returns to scale (or rather captures them in the $A$ variable):

$$
Q=A\left(K^{*}\right)^{\alpha}\left(L^{*}\right)^{\beta}\left(\mathrm{LA}^{*}\right)^{[1-(\alpha+\beta)]}
$$

where:

$Q=$ flow of output (GDP); $K^{*}=$ flow of services from augmented capital; $L^{*}=$ flow of services from augmented labor; and $\mathrm{LA}^{*}=$ flow of services from augmented labor; and $A=$ index of total factor productivity.

We can derive the basic growth accounting equation:

$$
G(Q)=G(A)+\alpha G\left(K^{*}\right)+\beta G\left(\mathrm{~L}^{*}\right)+[1-(\alpha+\beta)] G\left(\mathrm{LA}^{*}\right) .
$$

In the table we discuss issues involving the measurement and interpre-

\begin{tabular}{|c|c|c|}
\hline Variable & $\begin{array}{c}\text { How is the variable } \\
\text { augmented or adjusted? }\end{array}$ & $\begin{array}{c}\text { Comments on interpretation } \\
\text { of augmentation }\end{array}$ \\
\hline $\begin{array}{l}G(Q) \\
\text { Aggregate output } \\
\text { growth }\end{array}$ & $\begin{array}{l}\text { Adjust the flows of com- } \\
\text { modity and service output } \\
\text { for quality }\end{array}$ & $\begin{array}{l}\text { Adjustment involves index } \\
\text { number problems and } \\
\text { assumptions about the values } \\
\text { of components of products } \\
\text { and services }\end{array}$ \\
\hline $\begin{array}{l}G(A) \\
\text { Total factor } \\
\text { productivity } \\
\text { growth }\end{array}$ & & $\begin{array}{l}\text { Underlying growth in total } \\
\text { factor productivity are (1) } \\
\text { scale economies (stemming } \\
\text { from geographic externali- } \\
\text { ties and those internalized by } \\
\text { firms); (2) structural change } \\
\text { in the composition of output; } \\
\text { and (3) technological and } \\
\text { organizational change. It is } \\
\text { possible that all three factors } \\
\text { are correlated with } G\left(K^{*}\right) \text {. }\end{array}$ \\
\hline$G\left(K^{*}\right)$ & $\begin{array}{l}\text { Through changes in the } \\
\text { quality of capital, for } \\
\text { instance due to the chang- } \\
\text { ing vintage (age) of capital }\end{array}$ & $\begin{array}{l}\text { Controversy surrounds the } \\
\text { question of whether changes } \\
\text { in technology are embodied } \\
\text { in } K^{*} \text {. }\end{array}$ \\
\hline
\end{tabular}
tation of each of the five major variables, $Q, A, K^{*}, L^{*}$, and LA*. 
Table A.1: (Continued)

\begin{tabular}{|c|c|c|}
\hline$G\left(L^{*}\right)$ & $\begin{array}{l}\text { Raw labor input is augmented by } \\
\text { changes in the efficiency of labor } \\
e(L) \text {. Underlying changes in the } \\
\text { efficiency of labor are (1) changes } \\
\text { in the demographic, educational } \\
\text { composition of the labor force; } \\
\text { (2) changes in the health of the } \\
\text { labor force; (3) changes in hours } \\
\text { worked }(h) \text { per worker; and }(4) \\
\text { changes in incentives that impact } \\
\text { work intensity per hour worked }\end{array}$ & $\begin{array}{l}\text { The four factors underlying } \\
\text { efficiency of labor may be shaped } \\
\text { by (1) the organization and man- } \\
\text { agement of production units; } \\
\text { (2) the quality of managers; and } \\
\text { (3) the range of opportunities } \\
\text { open to workers (shaped by } \\
\text { geographic barriers and barri- } \\
\text { ers to achieving socioeconomic } \\
\text { mobility, for instance through } \\
\text { acquiring education, hence by } \\
\text { public policy) }\end{array}$ \\
\hline$G\left(\mathrm{LA}^{*}\right)$ & $\begin{array}{l}\text { Land — for instance agricultural } \\
\text { land - is augmented through the } \\
\text { application of fertilizers and irriga- } \\
\text { tion. Land is also augmented by } \\
\text { converting it from one use to } \\
\text { another, for instance from } \\
\text { wasteland or forest to arable land }\end{array}$ & $\begin{array}{l}\text { Technological progress in agricul- } \\
\text { ture may have a land augmenting } \\
\text { bias due to the relative price of } \\
\text { land services relative to labor } \\
\text { services or due to the elastici- } \\
\text { ties of supply of labor and land } \\
\text { (e.g.: inelastically supplied land } \\
\text { tends to promote augmentation } \\
\text { of land.) }\end{array}$ \\
\hline
\end{tabular}

In principle in analyzing the sources of growth it is important to decompose the growth of each of the three factors of production into their components, namely:

$G\left(K^{*}\right)=G\left(q_{K}\right)+G(K)$ where $q_{K}$ captures the average quality of capital services and $K$ is the flow of raw unadjusted capital services.

$G\left(L^{*}\right)=G[e(L)]+G(L)$, where the average efficiency of labor $e(L)$ depends upon hours worked $h$; intensity of work effort per hour worked; the demographic structure of the labor force (shaped by age and gender composition); the level of education and health of the population, especially those employed in the labor force; and barriers to exploiting potential opportunities (e.g., geographic isolation from markets may be a barrier); and incentives provided by the way production units are managed. $L$ is raw labor input.

$G\left(\mathrm{LA}^{*}\right)=G\left(q_{L}\right)+G(\mathrm{LA})$ where $q_{K}$ is the average quality of land that depends upon land use practice. 
Table A.2: Estimates of levels and growth rates for income, population, and income per capita for regions of the world and for china and Japan, 1500-1998.

A. Long-run estimates of growth in GDP per capita and population

\begin{tabular}{|c|c|c|c|c|c|c|}
\hline $\begin{array}{l}\text { Region/ } \\
\text { Country }\end{array}$ & $\begin{array}{c}1500- \\
1820\end{array}$ & $\begin{array}{c}1820- \\
1870\end{array}$ & $\begin{array}{c}1870- \\
1913\end{array}$ & $\begin{array}{c}1913- \\
1950\end{array}$ & $\begin{array}{c}1950- \\
1973\end{array}$ & $\begin{array}{c}1973- \\
1998\end{array}$ \\
\hline \multicolumn{7}{|c|}{ A.1. GDP per Capita(\%) } \\
\hline World & 0.05 & 0.53 & 1.3 & 0.91 & 2.93 & 1.33 \\
\hline $\begin{array}{l}\text { Western } \\
\text { Europe }\end{array}$ & 0.15 & 0.95 & 1.32 & 0.76 & 4.08 & 1.78 \\
\hline $\begin{array}{l}\text { Western } \\
\text { Offshoots a }\end{array}$ & 0.34 & 1.42 & 1.81 & 1.55 & 2.44 & 1.94 \\
\hline $\begin{array}{l}\text { Asia (except } \\
\text { Japan) }\end{array}$ & 0.00 & 0.15 & 0.38 & -0.02 & 2.92 & 3.54 \\
\hline $\begin{array}{l}\text { Latin } \\
\text { America }\end{array}$ & 0.15 & 0.1 & 1.81 & 1.42 & 2.52 & 0.99 \\
\hline $\begin{array}{l}\text { Eastern } \\
\text { Europe/ } \\
\text { former USSR }\end{array}$ & 0.1 & 0.64 & 1.15 & 1.5 & 3.49 & -1.1 \\
\hline Africa & 0.01 & 0.12 & 0.64 & 1.02 & 2.07 & 0.01 \\
\hline Japan & 0.09 & 0.19 & 1.48 & 0.89 & 8.05 & 2.34 \\
\hline China & n.e. & -0.25 & 0.1 & -0.62 & 2.86 & 5.39 \\
\hline Difference, & n.e. & 0.44 & 1.38 & 1.51 & 5.19 & -3.05 \\
\hline
\end{tabular}

Japan-China

A.2. Population

\begin{tabular}{lcccccc} 
World & 0.27 & 0.4 & 0.8 & 0.93 & 1.92 & 1.66 \\
$\begin{array}{l}\text { Western } \\
\text { Europe }\end{array}$ & 0.26 & 0.69 & 0.77 & 0.42 & 0.7 & 0.32 \\
$\begin{array}{l}\text { Western } \\
\begin{array}{l}\text { Offshoots }{ }^{\text {a }} \\
\text { Asia (except }\end{array}\end{array}$ & 0.43 & 2.87 & 2.07 & 1.25 & 1.55 & 1.02 \\
$\begin{array}{l}\text { Japan) } \\
\text { Latin }\end{array}$ & 0.29 & 015 & 0.55 & 0.92 & 2.19 & 1.86 \\
$\begin{array}{l}\text { America } \\
\text { Eastern }\end{array}$ & 0.34 & 0.87 & 1.21 & 0.34 & 1.31 & 0.54 \\
$\begin{array}{l}\text { Europe/ } \\
\text { former USSR }\end{array}$ & & & & & & \\
$\begin{array}{l}\text { Africa } \\
\text { Japan }\end{array}$ & 0.15 & 0.4 & 0.75 & 1.65 & 2.33 & 2.73 \\
China & 0.22 & 0.21 & 0.95 & 1.31 & 1.15 & 0.61 \\
$\begin{array}{l}\text { Difference, } \\
\text { Japan-China }\end{array}$ & n.e. & -0.12 & 0.47 & 0.61 & 2.1 & 2.74 \\
\hline
\end{tabular}


Table A.2: (Continued)

B. Levels of GDP per capita, long-term estimates (1990 Geary-Khamis Dollars)

\begin{tabular}{lccccccc}
\hline Region/Country & $\mathbf{1 5 0 0}$ & $\mathbf{1 8 2 0}$ & $\mathbf{1 8 7 0}$ & $\mathbf{1 9 1 3}$ & $\mathbf{1 9 5 0}$ & $\mathbf{1 9 7 3}$ & $\mathbf{1 9 9 0}$ \\
\hline World & 565 & 667 & 867 & 1510 & 2114 & 4104 & n.e. \\
Western Europe & 774 & 1232 & 1974 & 3473 & 4594 & 11,534 & n.e. \\
Western Offshoots a & 400 & 1201 & 2431 & 5257 & 9288 & 16,172 & n.e. \\
Asia (except Japan) & 572 & 575 & 543 & 640 & 635 & 1231 & n.e. \\
Latin America & 416 & 665 & 698 & 1511 & 2554 & 4531 & n.e. \\
Eastern Europe/ & 483 & 667 & 917 & 1501 & 2601 & 5729 & n.e. \\
former USSR & & & & & & & \\
Africa & 400 & 418 & 444 & 585 & 852 & 1365 & n.e. \\
Japan & 500 & 669 & 737 & 1387 & 1926 & 11,439 & 18,789 \\
China & n.e. & 600 & 530 & 552 & 439 & 839 & 1858 \\
Ratio (Japan/China) & n.e. & 1.12 & 1.39 & 2.51 & 4.39 & 13.63 & 10.11 \\
multiple & & & & & & & \\
\hline
\end{tabular}

C. Levels of population (in 1000s) for Japan and China, 1820-1998

\begin{tabular}{lccc}
\hline Date & Japan & China & Japan/China (\%) \\
\hline 1820 & 31,000 & 381,000 & 8.14 \\
1870 & 34,437 & 358,000 & 9.62 \\
1913 & 51,672 & 437,140 & 11.82 \\
1950 & 83,563 & 546,815 & 15.28 \\
1973 & 108,660 & 881,940 & 12.32 \\
1990 & 123,540 & $1,135,185$ & 10.88 \\
1998 & 126,486 & $1,242,700$ & 10.18 \\
\hline
\end{tabular}

D. Levels of GDP (Millions of 1990 Geary-Khamis international dollars), Japan and China, 1820-1998

\begin{tabular}{lrrr}
\hline Date & Japan & China & Japan/China $(\%)$ \\
\hline 1820 & 20,739 & 228,600 & 9.07 \\
1870 & 25,393 & 189,740 & 13.38 \\
1913 & 71,653 & 241,344 & 29.69 \\
1950 & 160,966 & 239,903 & 67.10 \\
1973 & $1,242,932$ & 740,048 & 167.95 \\
1990 & $2,321,153$ & $2,109,400$ & 110.04 \\
1998 & $2,581,576$ & $3,873,352$ & 66.65 \\
\hline
\end{tabular}


Table A.2: $\quad$ (Continued)

E. Share of world GDP, regions, and Japan and China, 1500-1990 (\%)

\begin{tabular}{|c|c|c|c|c|c|c|c|}
\hline Region/Country & 1500 & 1820 & 1870 & 1913 & 1950 & 1973 & 1990 \\
\hline World & 100 & 100 & 100 & 100 & 100 & 100 & 100 \\
\hline Western Europe & 17.9 & 23.6 & 33.6 & 33.5 & 26.3 & 25.7 & 20.6 \\
\hline Western Offshoots ${ }^{\text {a }}$ & 0.5 & 1.9 & 10.2 & 21.7 & 30.6 & 25.3 & 25.1 \\
\hline Asia (except Japan) & 62.1 & 56.2 & 36 & 21.9 & 15.5 & 16.4 & 29.5 \\
\hline Latin America & 2.9 & 2.0 & 2.5 & 4.5 & 7.9 & 8.7 & 8.7 \\
\hline $\begin{array}{l}\text { Eastern Europe/ } \\
\text { former USSR }\end{array}$ & 5.9 & 8.8 & 11.7 & 13.1 & 13.1 & 12.9 & 5.3 \\
\hline Africa & 7.4 & 4.5 & 3.7 & 2.7 & 3.6 & 3.3 & 3.1 \\
\hline Japan & 3.1 & 3.0 & 2.3 & 2.6 & 3.0 & 7.7 & 7.7 \\
\hline China & 34.17 & 22.42 & 7.75 & 3.9 & 1.8 & 7.0 & 11.6 \\
\hline
\end{tabular}

F. Growth rates for GDP per capita, Japan, China, Hong Kong, South Korea, and Taiwan, 1913-1999 (\%)

\begin{tabular}{lccccc}
\hline Country & $\mathbf{1 9 1 3 - 1 9 5 0}$ & $\mathbf{1 9 5 0 - 1 9 9 9}$ & $\mathbf{1 9 5 0 - 1 9 7 3}$ & $\mathbf{1 9 7 3 - 1 9 9 0}$ & $\mathbf{1 9 9 0 - 1 9 9 9}$ \\
\hline Japan & 0.9 & 4.9 & 8.1 & 3.0 & 0.9 \\
China & -0.6 & 4.2 & 2.9 & 4.8 & 6.4 \\
Hong Kong & n.e. & 4.6 & 5.2 & 5.4 & 1.7 \\
South Korea & 1.5 & 4.9 & 4.4 & 6.8 & 4.8 \\
Taiwan & 0.6 & 5.9 & 6.7 & 5.3 & 5.3 \\
Difference & n.e. & -0.4 & -2.3 & -0.6 & 4.7 \\
China-Hong & & & & & \\
Kong & & -1.7 & -3.8 & -0.5 & 1.1 \\
Difference & -1.2 & & & & \\
China-Taiwan & & &
\end{tabular}

${ }^{a}$ Western Offshoots = United States, Canada, Australia, New Zealand. n.e. $=$ not estimated.

Sources: Pages 126-127, 143, 146, 214-218 in Maddison (2006).

global distribution of output. Regarding the last point it is noteworthy that Asia accounted for over $60 \%$ of global output in 1500 , its percentage dropping thereafter bottoming out with a low of $15.5 \%$ in 1950 then climbing back somewhat. With the recent dramatic expansion of China's economy Asia's share is expected to grow to much higher levels than it enjoyed in the immediate aftermath of World War II. 
Structural change in the national output of China is the theme of Table A.3. Noteworthy are the following points: (1) between 1890 and 1933 there was a slight - but only slight — fall in the share of primary production in Chinese national income; (2) between 1950 and 1978, the drop in primary production as a share of Chinese output was dramatic, outstripping the decline between 1978 and 1995. Paralleling this decline was a massive expansion of the industrial sector; and (3) Shifting labor out of primary production into industry and construction played an important role in the growth of national income in post-1952 China, particularly in the period 1978-1995 after the reform period commenced.

Decomposition of growth in income per capita in terms of aggregate demand components for Japan over the period 1886-2000 is the focus of Panel A.1 of Table A.4. Noteworthy conclusions emanating from the table are: (1) a rise in the investment proportion over the periods 1886-1900, 1906-1925, 1931-1940, and especially 1956-1975; (2) a shift in the regime of net exports, pre-1951 net exports negative (imports exceeding imports) followed by a period in which net exports tended to be positive (and growing until the early 1990s). Panel A.2 documents the sharp decline in the proportion of Japan's national output generated by the primary sector.

Putting post-1950 Japanese and Chinese economic growth into a broader Asian context is the message of Table A.5. Two points are worth mentioning in the context of this table: (1) the gap in income per capita between most of China's East Asian neighbors and China - Japan, Taiwan, Hong Kong, and South Korea — widened between 1950 and 1979, shrinking thereafter; and (2) per capita income in China and India were quite similar through the period 1950-1979, after which China grew much faster than India.

Population size and the dynamics of population growth are the themes of Table A.6. Interesting findings culled from the data are: (1) over the period from the 17th century to 2000 the populations of both Japan and China expanded tenfold suggesting population growth per se is not a barrier to launching industrialization in the long-run nor is it a major determinant of the timing of the spread of the inorganic economy within a country; (2) population decline was significant in China in the wake of major rebellions - especially the Taiping Rebellion - that took place during the 1850s and 1960s; (3) between 1720 and 1950 Japan's population growth was virtually zero, growth being quite rapid in the century prior to 1720 and resuming after 1850; (4) Japan commenced the demographic transition during the period prior to 1940 while China did not; (5) average life expectancy 
Table A.3: Structural change in the Gross Domestic Product (GDP) of China, 1890-2004.

A.1. The composition of China's GDP in 1890, 1913, 1933 (\% in each sector) and changes between 1890 and 1933 in the share of the sectors

\begin{tabular}{lrrrc}
\hline Sector & & & & Change in \% \\
$\mathbf{1 8 9 0 - 1 9 3 3}$
\end{tabular}

A.2. Index of GDP and sector outputs for $1933(1914=100)$ and growth rates $(\%)$ for GDP and the sectors for the period 1914/1933

\begin{tabular}{lcc}
\hline Item & Index & Growth rate $(\%)$ \\
\hline Agriculture & 117.0 & 1.0 \\
Modern industry and transport & 419.2 & 8.8 \\
Other industry and transport & 100.4 & 0.0 \\
Services & 125.2 & 1.3 \\
GDP & 126.4 & 1.4 \\
\hline
\end{tabular}

A.3. Shares of broad sectors in GDP (\%) and changes in the shares, 1890-1995

\begin{tabular}{lcccc}
\hline \multicolumn{5}{c}{ Shares of sectors (\%) } \\
\hline Sector & $\mathbf{1 8 9 0}$ & $\mathbf{1 9 5 2}$ & $\mathbf{1 9 7 8}$ & $\mathbf{1 9 9 5}$ \\
\hline $\begin{array}{l}\text { Farming, fishery, } \\
\text { forestry }\end{array}$ & 68.5 & 58.6 & 33.7 & 23.2 \\
\begin{tabular}{l} 
Industry \\
\hline
\end{tabular} & 8.1 & 9.9 & 34.7 & 41.1 \\
\hline
\end{tabular}


Table A.3: (Continued)

\begin{tabular}{|c|c|c|c|c|}
\hline Construction & 1.7 & 1.7 & 3.3 & 5.8 \\
\hline $\begin{array}{l}\text { Transport and } \\
\text { communications }\end{array}$ & 5.5 & 2.4 & 3.5 & 5.2 \\
\hline $\begin{array}{l}\text { Commerce and } \\
\text { restaurants }\end{array}$ & 8.2 & 6.5 & 5.0 & 7.3 \\
\hline $\begin{array}{l}\text { Other services (includ- } \\
\text { ing government) }\end{array}$ & 8.0 & 20.9 & 19.7 & 17.4 \\
\hline GDP & 100.0 & 100.0 & 100.0 & 100.0 \\
\hline \multicolumn{5}{|c|}{ Change in shares of sectors } \\
\hline Sector & $1890 / 1995$ & $1890 / 1952$ & $1952 / 1978$ & $1978 / 1995$ \\
\hline $\begin{array}{l}\text { Farming, fishery, } \\
\text { forestry }\end{array}$ & -45.3 & -9.9 & -24.9 & -10.5 \\
\hline Industry & +33.0 & +1.8 & +24.8 & +6.4 \\
\hline Construction & +4.1 & 0.0 & +1.6 & +2.5 \\
\hline $\begin{array}{l}\text { Transport and } \\
\text { communications }\end{array}$ & -0.3 & -3.1 & 1.1 & +1.7 \\
\hline $\begin{array}{l}\text { Commerce and } \\
\text { restaurants }\end{array}$ & -0.9 & -1.7 & -1.5 & +2.3 \\
\hline $\begin{array}{l}\text { Other services (includ- } \\
\text { ing government) }\end{array}$ & +9.4 & +12.9 & -1.2 & -2.3 \\
\hline
\end{tabular}

A.4. Composition of government revenue sources in 1753 and $1908(\%)$

\begin{tabular}{lcc}
\hline Item & $\mathbf{1 7 5 3}$ & $\mathbf{1 9 0 8}$ \\
\hline Land Tax & $81.5 \%$ & $43.5 \%$ \\
Salt Tax & 9.4 & 12.7 \\
Native Customs & 7.3 & 1.7 \\
Maritime Customs & - & 14.0 \\
Likin & - & 9.1 \\
Miscellaneous & 1.8 & 19.1 \\
Total & 100.0 & 100.0 \\
\hline
\end{tabular}

A.5. Composition of government revenue and expenditures (\%) and percent of GDP for government revenue and expenditures, 1936

\begin{tabular}{lcccc}
\hline \multicolumn{3}{c}{ Share of revenue } & Revenue/GDP \\
\hline Customs & Salt tax & $\begin{array}{c}\text { Consolidated } \\
\text { taxes }\end{array}$ & $\begin{array}{c}\text { Other (not } \\
\text { borrowing) }\end{array}$ & \\
\hline $33.3 \%$ & $22.5 \%$ & $16.5 \%$ & $27.7 \%$ & $2.8 \%$ \\
\hline
\end{tabular}


Table A.3: (Continued)

\begin{tabular}{|c|c|c|c|}
\hline \multicolumn{3}{|c|}{ Share of expenditure } & \multirow[t]{2}{*}{ Expenditure/GDP } \\
\hline Military & Indemnity/Debt service & Other & \\
\hline $33.0 \%$ & $24.9 \%$ & $42.1 \%$ & $4.0 \%$ \\
\hline
\end{tabular}

A.6. Growth rates for GDP by sector, 1890-1995

\begin{tabular}{lcccc}
\hline Sector & $\mathbf{1 8 9 0 - 1 9 5 2}$ & $\mathbf{1 9 5 2 - 1 9 9 5}$ & $\mathbf{1 9 5 2 - 1 9 7 8}$ & $\mathbf{1 9 7 8 - 1 9 9 5}$ \\
\hline $\begin{array}{l}\text { Farming, fishery, } \\
\text { forestry }\end{array}$ & 0.3 & 3.4 & 2.2 & 5.1 \\
Industry & 1.7 & 9.2 & 9.6 & 8.5 \\
Construction & 1.6 & 8.7 & 7.2 & 11.1 \\
Transport and & 0.9 & 7.6 & 6.0 & 10.0 \\
communications & & & & \\
Commerce and & 0.8 & 5.9 & 3.3 & 9.9 \\
restaurants & & & & \\
Other services (includ- & 1.1 & 5.2 & 4.2 & 6.7 \\
ing government) & & & & \\
GDP & 0.6 & 5.6 & 4.4 & 7.5 \\
GDP per capita & 0.0 & 3.8 & 2.3 & 6.0 \\
GDP per worker & 0.0 & 2.9 & 1.8 & 4.7 \\
Export volume & 1.6 & 9.2 & 6.4 & 13.5 \\
\hline
\end{tabular}

A.7. Growth rates for GDP, various components of GDP, population $(P)$, and GDP per Capita $(\mathrm{GDP} / \mathrm{P}), 1979-2000$

\begin{tabular}{lccc}
\hline Item & $\mathbf{1 9 7 9 - 1 9 8 4}$ & $\mathbf{1 9 8 5 - 1 9 9 5}$ & $\mathbf{1 9 9 6 - 2 0 0 0}$ \\
\hline GDP & 8.8 & 9.7 & 8.2 \\
Agriculture & 7.1 & 4.0 & 3.4 \\
Industry & 8.2 & 12.8 & 9.6 \\
Services & 11.6 & 9.7 & 8.2 \\
Foreign trade & 14.3 & 15.2 & 9.8 \\
Imports & 12.7 & 13.4 & 9.5 \\
Exports & 15.9 & 17.2 & 10.0 \\
$P$ & 1.4 & 1.4 & 0.9 \\
GDP $/ P$ & 7.1 & 8.3 & 7.1 \\
\hline
\end{tabular}


Table A.3: $\quad$ (Continued)

A.8. Growth rates for GDP(\%), employment(\%), and labor productivity for total GDP and for its major sectors (\%), 1952-1995

\begin{tabular}{|c|c|c|c|}
\hline Sector & $1952-1978$ & $1978-1995$ & $\begin{array}{c}\text { Change between two } \\
\text { periods }(2)-(1)\end{array}$ \\
\hline \multicolumn{4}{|c|}{ Agriculture } \\
\hline GDP & 2.20 & 5.15 & +2.95 \\
\hline Employment & 2.02 & 0.84 & -1.18 \\
\hline Labor productivity & 0.17 & 4.27 & +4.10 \\
\hline \multicolumn{4}{|c|}{ Industry and construction } \\
\hline GDP & 9.29 & 8.82 & -0.47 \\
\hline Employment & 5.84 & 4.83 & -1.01 \\
\hline Labor productivity & 3.25 & 3.81 & +0.56 \\
\hline \multicolumn{4}{|c|}{ Tertiary } \\
\hline GDP & 4.18 & 7.86 & +3.09 \\
\hline Employment & 3.20 & 6.73 & +3.53 \\
\hline Labor productivity & 0.96 & 1.05 & +0.09 \\
\hline \multicolumn{4}{|c|}{ Whole economy } \\
\hline GDP & 4.40 & 7.49 & +3.09 \\
\hline Employment & 2.57 & 2.62 & +0.05 \\
\hline Labor productivity & 1.78 & 4.74 & +2.96 \\
\hline $\begin{array}{l}\text { Impact of shift in sectoral } \\
\text { Reallocation of labor on } \\
\text { GDP growth }\end{array}$ & 0.92 & 1.44 & +0.52 \\
\hline
\end{tabular}

A.9. Growth rate of output per worker by broad sector(\%), 1978-2004

\begin{tabular}{lccc}
\hline Sector & $\mathbf{1 9 7 8 - 2 0 0 4}$ & $\mathbf{1 9 7 8 - 1 9 8 8}$ & $\mathbf{1 9 8 8 - 2 0 0 4}$ \\
\hline Total & 6.96 & 6.74 & 7.09 \\
Agriculture & 6.76 & 5.70 & 7.43 \\
Nonagriculture & 4.65 & 2.47 & 6.02 \\
Nonagriculture: state & 4.87 & 3.30 & 5.86 \\
$\begin{array}{l}\text { owned } \\
\text { Nonagriculture: nonstate }\end{array}$ & 5.59 & 3.89 & 6.67 \\
owned & & & \\
\hline
\end{tabular}

Sources: For Panels A.1, A.3, A.6, and A.8 various tables in Maddison (1998). For Panels A.2 and A.5 p. 15 and p. 272 in Rawski (1989). For Panel A.4 p. 176 in Perkins (1969). For Panel A.7 p. 482 in Huang et al. (2008). For Panel A.9 p. 696 in Brandt et al. (2008). 
Table A.4: Growth of GDP per capita and the structure of Gross Domestic Expenditure and aggregate output in Japan, 1886-2000

A.1. Growth of Income per Capita $[\mathrm{G}(\mathrm{y})]$, Percentage of Gross Domestic Expenditure from Consumption (C), Investment (I), Government Spending (G), Exports (EX), Imports (IM) and Net Exports $(\mathrm{NX}=\mathrm{EX}-\mathrm{IM})$

\begin{tabular}{|c|c|c|c|c|c|c|c|}
\hline \multirow[b]{2}{*}{ Period } & \multirow[b]{2}{*}{$\mathbf{G}(\mathbf{y})$} & \multicolumn{6}{|c|}{ Structure of Gross Domestic Expenditure (\%) } \\
\hline & & $\mathbf{C}$ & I & G & EX & IM & NX \\
\hline 1886-1890 & $0.97 \%$ & $85.2 \%$ & $9.0 \%$ & $6.9 \%$ & $3.2 \%$ & $4.2 \%$ & $-0.9 \%$ \\
\hline 1891-1895 & 2.08 & 84.0 & 9.4 & 7.9 & 3.7 & 5.1 & -1.4 \\
\hline 1896-1900 & 3.13 & 85.4 & 12.1 & 7.5 & 4.9 & 9.9 & -5.0 \\
\hline 1901-1905 & 1.66 & 80.2 & 10.6 & 14.3 & 6.5 & 11.7 & -5.2 \\
\hline 1906-1910 & 0.90 & 79.6 & 13.5 & 11.3 & 8.0 & 12.4 & -4.4 \\
\hline 1911-1915 & 3.95 & 79.0 & 15.6 & 9.1 & 10.7 & 14.4 & -3.7 \\
\hline 1916-1920 & 2.87 & 74.9 & 17.9 & 8.1 & 13.8 & 14.6 & -0.8 \\
\hline 1921-1925 & 0.15 & 82.3 & 18.8 & 9.0 & 10.4 & 20.4 & -10.1 \\
\hline 1926-1930 & -0.25 & 79.8 & 17.8 & 10.3 & 14.5 & 22.3 & -7.8 \\
\hline 1931-1935 & 4.14 & 74.0 & 16.5 & 12.7 & 19.3 & 22.5 & -3.2 \\
\hline 1936-1940 & 5.19 & 63.8 & 25.7 & 12.9 & 21.2 & 23.4 & -2.3 \\
\hline 1941-1945 & -9.93 & n.e. & n.e. & n.e. & n.e. & n.e. & n.e. \\
\hline 1946-1950 & 8.36 & 62.2 & 21.1 & 9.9 & 4.1 & 6.8 & -2.6 \\
\hline 1951-1955 & 6.74 & 61.9 & 17.8 & 14.8 & 8.3 & 6.9 & +1.4 \\
\hline 1956-1960 & 8.51 & 61.6 & 22.8 & 11.9 & 8.8 & 8.0 & +0.8 \\
\hline 1961-1965 & 8.01 & 56.8 & 30.5 & 9.6 & 9.5 & 9.7 & -0.2 \\
\hline 1966-1970 & 9.03 & 55.5 & 34.3 & 7.8 & 12.1 & 11.1 & +1.0 \\
\hline 1971-1975 & 3.11 & 53.8 & 36.3 & 8.6 & n.e. & n.e. & +0.9 \\
\hline 1976-1980 & 3.58 & 57.3 & 31.7 & 10.5 & n.e. & n.e. & +0.5 \\
\hline 1981-1985 & 2.89 & 55.1 & 29.3 & 13.8 & n.e. & n.e. & +1.9 \\
\hline 1986-1990 & 4.36 & 53.8 & 30.6 & 13.3 & n.e. & n.e. & +2.3 \\
\hline 1991-1995 & 1.15 & 54.5 & 29.8 & 13.8 & n.e. & n.e. & +1.9 \\
\hline 1996-2000 & 0.66 & 55.9 & 27.4 & 15.5 & n.e. & n.e. & +1.3 \\
\hline
\end{tabular}

A.2. Percentage of GDP in Broad Sectors, Primary (P), Secondary (S) and Tertiary (T)

\begin{tabular}{llll}
\hline Period & P & S & T \\
\hline $1951-1955$ & $18.4 \%$ & $34.6 \%$ & $46.9 \%$ \\
$1956-1960$ & 14.9 & 37.9 & 47.3 \\
$1961-1965$ & 10.6 & 41.0 & 48.4 \\
$1966-1970$ & 7.8 & 41.1 & 51.1 \\
\hline
\end{tabular}


Table A.4: (Continued)

\begin{tabular}{llll}
\hline $1971-1975$ & 5.4 & 41.5 & 53.2 \\
$1976-1980$ & 4.5 & 38.0 & 57.6 \\
$1981-1985$ & 3.2 & 36.8 & 60.0 \\
$1986-1990$ & 2.6 & 35.9 & 61.5 \\
$1991-1995$ & 2.0 & 32.6 & 65.3 \\
$1996-2000$ & 1.5 & 29.1 & 69.3 \\
\hline
\end{tabular}

Notes: n.e. = not estimated.

Source: Pages 355 and 359 in Mosk (2008).

Table A.5: Income per capita in selected Asian countries (figures in 1990 International Geary-Khamis Dollars) and income per capita relative to that for China.

A. Income per Capita (1990 International Geary-Khamis Dollars)

\begin{tabular}{lcrcccc}
\hline Period & China & Japan & Taiwan & Hong Kong & South Korea & India \\
\hline $1950-1954$ & 513 & 2292 & 1066 & 2379 & 842 & 640 \\
$1955-1959$ & 644 & 3141 & 1339 & 2828 & 1082 & 698 \\
$1960-1964$ & 605 & 4799 & 1700 & 3688 & 1158 & 774 \\
$1965-1969$ & 714 & 7287 & 2386 & 4948 & 1533 & 799 \\
$1970-1974$ & 812 & 10615 & 3640 & 6466 & 2579 & 851 \\
$1975-1979$ & 928 & 12166 & 5022 & 8535 & 3754 & 917 \\
$1980-1984$ & 1205 & 14069 & 6749 & 11536 & 4671 & 1001 \\
$1985-1989$ & 1694 & 16478 & 9319 & 15216 & 6899 & 1158 \\
$1900-1994$ & 2130 & 19411 & 11144 & 19119 & 9853 & 1356 \\
$1995-1999$ & 2964 & 20913 & 14374 & 20979 & 12583 & 1681 \\
\hline
\end{tabular}

B. Income per capita relative to China's income per capita

\begin{tabular}{lccccc}
\hline Period & Japan & Taiwan & Hong Kong & South Korea & India \\
\hline $1950-1954$ & 4.46 & 2.08 & 4.66 & 1.64 & 1.26 \\
$1955-1959$ & 4.87 & 2.08 & 4.40 & 1.69 & 1.09 \\
$1960-1964$ & 7.99 & 2.83 & 6.13 & 1.93 & 1.29 \\
$1965-1969$ & 10.23 & 3.35 & 6.93 & 2.15 & 1.12 \\
$1970-1974$ & 13.07 & 4.47 & 7.95 & 3.17 & 1.05 \\
$1975-1979$ & 13.13 & 5.40 & 9.18 & 4.04 & 0.99 \\
$1980-1984$ & 11.75 & 5.60 & 9.61 & 3.88 & 0.84 \\
$1985-1989$ & 9.74 & 5.51 & 8.96 & 4.06 & 0.69 \\
$1900-1994$ & 9.20 & 5.25 & 9.02 & 4.64 & 0.64 \\
$1995-1999$ & 7.07 & 4.85 & 7.12 & 4.26 & 0.57 \\
\hline
\end{tabular}

Source: Maddison (2006): pp. 304-305 (Table C3-c). 
Table A.6: Population, education, and human development in China and Japan, 1640-2004.

A. Population size and dynamics

A.1. Estimates of China's population size by Maddison, various indices, and alternative official estimates (for the period 1750-1850), 1640-2000

\begin{tabular}{|c|c|c|c|c|c|}
\hline \multirow[t]{2}{*}{ Year } & \multicolumn{4}{|c|}{ Maddison estimates } & \multirow[t]{2}{*}{$\begin{array}{l}\text { Alterna- } \\
\text { tive official } \\
\text { estimate }\end{array}$} \\
\hline & $\begin{array}{l}\text { Number } \\
(1000 s)\end{array}$ & $\begin{array}{l}\text { Index }(1950 \\
\quad=100)\end{array}$ & $\begin{array}{c}\text { Index }(1760= \\
100)\end{array}$ & $\begin{array}{l}\text { Index }(1640 \\
\quad=100)\end{array}$ & \\
\hline 1650 & 123,000 & 22.5 & 44.8 & 94.6 & - \\
\hline 1700 & 138,000 & 25.2 & 50.3 & 106.2 & - \\
\hline 1750 & 260,000 & 47.6 & 94.7 & 200.0 & 179,539 \\
\hline 1800 & 341,600 & 62.5 & 124.4 & 262.8 & 295,273 \\
\hline 1850 & 412,000 & 75.4 & 150.0 & 316.9 & 429,931 \\
\hline 1860 & 377,000 & 69.0 & 137.3 & 290.0 & - \\
\hline 1870 & 358,000 & 65.5 & 130.4 & 275.4 & - \\
\hline 1880 & 368,000 & 67.3 & 134.0 & 283.1 & - \\
\hline 1890 & 380,000 & 69.5 & 138.4 & 292.3 & - \\
\hline 1900 & 400,000 & 73.2 & 145.7 & 307.7 & - \\
\hline 1910 & 423,000 & 77.4 & 154.0 & 325.4 & - \\
\hline 1920 & 472,000 & 86.3 & 171.9 & 363.1 & - \\
\hline 1930 & 489,000 & 89.4 & 178.1 & 376.2 & - \\
\hline 1940 & 518,770 & 94.9 & 188.9 & 399.1 & - \\
\hline 1950 & 546,815 & 100.0 & 199.1 & 420.6 & - \\
\hline 1960 & 667,070 & 122.0 & 242.9 & 513.1 & - \\
\hline 1970 & 818,315 & 149.7 & 298.0 & 629.5 & - \\
\hline 1980 & 981,235 & 179.5 & 357.3 & 754.8 & - \\
\hline 1990 & $1,135,185$ & 207.6 & 413.4 & 873.2 & - \\
\hline 2000 & $1,275,392$ & 233.2 & 464.5 & 981.1 & - \\
\hline
\end{tabular}

A.2. Population totals $(P)$, birth $(b)$ and death rates $(d)$ per thousand population, the natural rate of increase $(\mathrm{nri}=b-d)$, and urbanization $(u \%)$, China, 1950-1984

\begin{tabular}{lccccc}
\hline Period & $\boldsymbol{P ( 1 0 0 0 s )}$ & $\boldsymbol{b}$ & $\boldsymbol{d}$ & nri & $\boldsymbol{u} \%$ \\
\hline $1950-1954$ & 570,328 & 37.3 & 16.7 & 20.6 & $12.1 \%$ \\
$1955-1959$ & 644,294 & 30.5 & 12.2 & 18.3 & 15.6 \\
$1960-1964$ & 677,974 & 31.7 & 14.3 & 17.4 & 18.3 \\
$1965-1969$ & 765,306 & 35.2 & 8.6 & 26.7 & 17.7 \\
$1970-1974$ & 870,816 & 29.3 & 7.4 & 21.9 & 17.2 \\
\hline
\end{tabular}


Table A.6: (Continued)

\begin{tabular}{lccccc}
\hline $1975-1979$ & 949,824 & 19.6 & 6.8 & 12.8 & 17.8 \\
$1980-1984$ & $1,012,576$ & 19.1 & 6.6 & 12.5 & 20.8 \\
2000 & n.e. & n.e. & n.e. & n.e. & 36.2 \\
\hline
\end{tabular}

A.3. Life expectancy for males (LFM) and females (LFF), infant mortality rate for males (imrm) and females (imrf), total fertility rate (TFR), and mean household size (MHS), China, 1929/1931-2000

\begin{tabular}{lcccccc}
\hline Date(s) & LEM & LFF & imrm & imrf & TFR & MHS \\
\hline $1929-1931$ & 25.0 & 24.0 & n.e. & n.e. & n.e. & n.e. \\
1950 & 42.2 & 45.6 & 145.9 & 130.2 & n.e. & n.e. \\
1955 & n.e. & n.e. & n.e. & n.e. & 6.3 & n.e. \\
1960 & n.e. & n.e. & n.e. & n.e. & 4.0 & n.e. \\
1982 & 66.5 & 69.4 & 36.5 & 34.5 & 2.9 & 4.41 \\
1990 & 66.9 & 71.0 & 32.2 & 36.8 & 2.3 & 3.96 \\
2000 & 71.0 & 74.8 & 20.8 & 29.2 & 1.6 & 3.44 \\
\hline
\end{tabular}

A.4. Infant mortality rate (imr), life expectancy for males (LEM), and for females (LEF), gross reproduction rate (grr), and net reproduction rate (nrr), Japan, $1891 / 1895-1996 / 2000$

\begin{tabular}{lccccc}
\hline Period & imr & LEM & LEF & grr & nrr \\
\hline $1891-1895$ & - & 42.8 & 44.3 & - & - \\
$1901-1905$ & 152.0 & 43.9 & 44.9 & - & - \\
$1911-1915$ & 156.7 & 44.3 & 44.7 & - & - \\
$1921-1925$ & 159.3 & 42.3 & 43.2 & n.e. & n.e. \\
$1926-1930$ & 136.6 & 44.8 & 46.5 & n.e. & n.e. \\
$1931-1935$ & 120.4 & 46.9 & 49.9 & n.e. & n.e. \\
$1946-1950$ & 65.3 & 54.8 & 58.4 & 2.06 & 1.69 \\
$1951-1955$ & 48.0 & 63.6 & 67.8 & 1.34 & 1.20 \\
$1956-1960$ & 35.9 & 65.3 & 70.2 & 1.01 & 0.95 \\
$1961-1965$ & 23.4 & 67.7 & 72.9 & 0.98 & 0.95 \\
$1966-1970$ & 15.4 & 69.3 & 74.7 & 0.99 & 0.96 \\
$1971-1975$ & 11.2 & 71.7 & 76.9 & 1.01 & 0.98 \\
$1976-1980$ & 8.4 & 73.4 & 78.7 & 0.87 & 0.86 \\
$1981-1985$ & 6.3 & 74.8 & 80.5 & 0.87 & 0.85 \\
$1986-1990$ & 4.8 & 75.9 & 81.9 & 0.80 & 0.79 \\
$1991-1995$ & 4.3 & 76.4 & 82.9 & 0.72 & 0.71 \\
$1996-2000$ & 3.5 & 77.7 & 84.6 & 0.67 & 0.67 \\
\hline
\end{tabular}


Table A.6: (Continued)

A.5. Population $(P)$ and an index for population with $1950=100$ (INDP), birth $(b)$ and death rates $(d)$, the natural rate of increase (nri), urbanization $(u \%)$, proportion of population in the six big cities (b6c\%), Japan, 1600-2000

\begin{tabular}{|c|c|c|c|c|c|c|c|}
\hline Period/Year & $P(1000 s)$ & INDP & $b$ & $d$ & nri & $u \%$ & b6c\% \\
\hline 1600 & 12,000 & 14.3 & - & - & - & - & - \\
\hline 1650 & 17,180 & 20.4 & - & - & - & - & - \\
\hline 1700 & 27,690 & 32.9 & - & - & - & - & - \\
\hline 1720 & 31,280 & 37.2 & - & - & - & - & - \\
\hline 1730 & 32,080 & 38.1 & - & - & - & - & - \\
\hline 1750 & 31,100 & 37.0 & - & - & - & - & - \\
\hline 1800 & 30,650 & 36.4 & - & - & - & - & - \\
\hline 1850 & 32,280 & 38.4 & - & - & - & - & - \\
\hline 1872 & 33,110 & 39.4 & - & - & - & - & - \\
\hline 1886-1890 & 39,130 & 46.5 & 28.8 & 20.8 & 8.0 & - & - \\
\hline 1891-1895 & 40,864 & 48.6 & 29.0 & 21.4 & 7.6 & - & - \\
\hline 1896-1900 & 42,906 & 51.0 & 31.7 & 21.1 & 10.5 & 12.4 & n.e. \\
\hline 1901-1905 & 45,525 & 54.1 & 32.5 & 21.0 & 11.5 & 15.0 & n.e. \\
\hline 1906-1910 & 48,031 & 57.1 & 33.6 & 21.5 & 12.1 & 17.3 & n.e. \\
\hline 1911-1915 & 51,305 & 61.0 & 34.5 & 20.7 & 13.9 & 17.5 & n.e. \\
\hline 1916-1920 & 54,673 & 65.0 & 33.7 & 24.1 & 9.6 & 18.9 & 9.8 \\
\hline 1921-1925 & 58,158 & 69.1 & 34.7 & 21.9 & 12.8 & 21.6 & 11.1 \\
\hline 1926-1930 & 62,581 & 74.4 & 33.4 & 19.3 & 14.1 & 24.0 & 11.8 \\
\hline 1931-1935 & 67,377 & 80.1 & 31.6 & 17.9 & 13.7 & 33.0 & 18.3 \\
\hline 1936-1940 & 71,014 & 84.4 & 28.8 & 17.3 & 11.5 & 38.3 & 20.0 \\
\hline 1941-1945 & 73,116 & 86.9 & 31.2 & 16.3 & 14.9 & n.e. & n.e. \\
\hline 1946-1950 & 79,948 & 95.1 & 32.2 & 12.3 & 20.0 & 35.3 & 11.9 \\
\hline 1951-1955 & 80,065 & 95.2 & 21.9 & 8.7 & 13.2 & 56.3 & 15.9 \\
\hline 1956-1960 & 91,962 & 109.3 & 17.7 & 7.7 & 9.9 & 63.5 & 16.5 \\
\hline 1961-1965 & 96,403 & 114.6 & 17.5 & 7.2 & 10.3 & 68.1 & 17.3 \\
\hline 1966-1970 & 101,553 & 120.7 & 17.8 & 6.8 & 11.0 & 72.2 & 18.1 \\
\hline 1971-1975 & 109,062 & 129.7 & 18.7 & 6.5 & 12.2 & 75.9 & 16.9 \\
\hline 1976-1980 & 115,133 & 136.9 & 14.9 & 6.1 & 8.7 & 76.2 & 16.0 \\
\hline 1981-1985 & 119,342 & 141.9 & 12.6 & 6.2 & 6.4 & 76.7 & 15.7 \\
\hline 1986-1990 & 122,692 & 145.9 & 10.7 & 6.4 & 4.3 & 77.4 & 15.5 \\
\hline 1991-1995 & 124,888 & 148.5 & 9.8 & 7.0 & 2.7 & 77.4 & 15.0 \\
\hline 1996-2000 & 126,216 & 150.0 & 9.5 & 7.5 & 2.0 & 78.7 & 15.2 \\
\hline
\end{tabular}


Table A.6: (Continued)

A.6. The pace of the demographic transition in Japan, 1930-1960: Values of age standardized death rates (asdr), infant mortality rates (imr), and the Hutterite index of marital fertility $\left(I_{g}\right)$ for the prefectures of Japan classified by percentage of male labor force engaged in primary industry in 1930 (pmlpi)

Mortality

\begin{tabular}{lllllllc}
\hline & \multicolumn{3}{c}{ Age standardized death rate (asdr) } & & \multicolumn{2}{c}{ Infant mortality (imr) } \\
\cline { 2 - 3 } Pmlpi & $\mathbf{1 9 0 8}$ & $\mathbf{1 9 3 0}$ & $\mathbf{1 9 5 0}$ & $\mathbf{1 9 6 0}$ & & $\mathbf{1 9 2 0}$ & $\mathbf{1 9 6 0}$ \\
\hline Under 30\% & 2572 & 1897 & 1075 & 712 & & 184 & 24 \\
$30 \%-49 \%$ & 2213 & 1921 & 1131 & 848 & & 161 & 32 \\
$50 \%-54 \%$ & 2404 & 1969 & 1184 & 765 & & 169 & 35 \\
$55 \%-59 \%$ & 2119 & 1825 & 1145 & 755 & & 158 & 34 \\
$60 \%$ and over & 2065 & 1985 & 1277 & 815 & & 163 & 38 \\
\hline
\end{tabular}

Fertility $\left(I_{g}\right)$

\begin{tabular}{lcccccc}
\hline & \multicolumn{3}{c}{ Rural } & \multicolumn{3}{c}{ Urban } \\
\cline { 2 - 7 } Pmlpi & $\mathbf{1 9 3 0}$ & $\mathbf{1 9 5 0}$ & $\mathbf{1 9 6 0}$ & $\mathbf{1 9 3 0}$ & $\mathbf{1 9 5 0}$ & $\mathbf{1 9 6 0}$ \\
\hline Under 30\% & 0.52 & 0.50 & 0.30 & 0.43 & 0.44 & 0.28 \\
$30 \%-49 \%$ & 0.54 & 0.50 & 0.29 & 0.43 & 0.45 & 0.28 \\
$50 \%-54 \%$ & 0.57 & 0.50 & 0.28 & 0.46 & 0.44 & 0.28 \\
$55 \%-59 \%$ & 0.58 & 0.53 & 0.30 & 0.48 & 0.45 & 0.28 \\
$60 \%$ and over & 0.60 & 0.56 & 0.42 & 0.50 & 0.49 & 0.29 \\
\hline
\end{tabular}

B. The biological standard of living and the human development index

B.1. Male standing height $(\mathrm{msh})$ at ages 6,12 , and 18 and estimates of the human development index (HDI), Japan, 1901-2000

\begin{tabular}{lccccccc}
\hline \multicolumn{3}{c}{ Male Standing Height } & $($ msh $)$ at Ages: & & \multicolumn{2}{c}{ Human Development Index } \\
\cline { 1 - 2 } Period & $\mathbf{6}$ & $\mathbf{1 2}$ & $\mathbf{1 8}$ & & Year & HDI \\
\hline $1901-1910$ & 106.7 & 133.6 & 159.2 & & 1910 & 0.61 \\
$1911-1920$ & 106.9 & 134.4 & 160.8 & & 1920 & 0.64 \\
$1921-1930$ & 107.7 & 136.2 & 161.6 & & 1930 & 0.65 \\
$1931-1940$ & 108.8 & 138.2 & 162.9 & & 1940 & 0.70 \\
$1941-1950$ & 108.5 & 138.2 & 162.9 & & 1950 & 0.69 \\
$1951-1960$ & 110.3 & 139.3 & 165.0 & & 1960 & 0.75 \\
$1961-1970$ & 113.4 & 144.9 & 157.7 & & 1970 & 0.83 \\
$1971-1980$ & 115.3 & 148.6 & 169.0 & & 1980 & 0.89 \\
$1981-1990$ & 116.4 & 150.4 & 170.6 & & 1990 & 0.90 \\
$1990-2000$ & 116.8 & 152.2 & 171.1 & & 2000 & 0.92
\end{tabular}


Table A.6: (Continued)

$$
\text { C. Education }
$$

C.1. Average years of schooling in China and Japan (years of education per person aged 15-64) and the ratio (Japan/China), 1950-1992

\begin{tabular}{lcrc}
\hline Year & China & Japan & Japan/China \\
\hline 1950 & 1.60 & 9.11 & 5.69 \\
1973 & 4.09 & 12.09 & 2.96 \\
1992 & 8.50 & 14.86 & 1.75 \\
\hline
\end{tabular}

C.2. Indices $(1960=100)$ for the number of senior and junior middle schools in cities, towns, and rural districts, China, 1964-1978

\begin{tabular}{lrrrrrrr}
\hline & \multicolumn{3}{c}{ Senior middle schools } & & \multicolumn{3}{c}{ Junior middle schools } \\
\cline { 2 - 3 } Period & Cities & Towns & Rural & & Cities & Towns & Rural \\
\hline $1964-1965$ & 99.3 & 100.0 & 100.0 & & 105.2 & 94.5 & 94.4 \\
$1971-1975$ & 328.7 & 175.1 & 3369.7 & & 91.3 & 104.6 & 701.9 \\
$1976-1978$ & 540.6 & 277.3 & 7483.9 & & 77.9 & 133.1 & 1250.9 \\
\hline
\end{tabular}

C.3. Years of schooling completed (SCY) and estimated rates of return on schooling: High school to college (COLR), high school to technical school (TECR), junior high to high school (HSR), and primary to junior high (JHR): Urban China, 1988-2001

\begin{tabular}{lrcccc}
\hline & & \multicolumn{4}{c}{ Estimated rates of return } \\
\cline { 3 - 6 } Period & SCY & COLR (\%) & TECR (\%) & HSR (\%) & JHR (\%) \\
\hline $1988-1989$ & 4.3 & 13.3 & 4.5 & 11.3 & 15.6 \\
$1990-1994$ & 5.2 & 20.3 & 9.9 & 11.4 & 14.2 \\
$1995-1999$ & 7.6 & 28.4 & 13.6 & 17.1 & 14.3 \\
$2000-2001$ & 10.2 & 38.0 & 17.0 & 21.0 & 15.1 \\
\hline
\end{tabular}

C.4. Estimated rates of return to schooling by ownership sector, China, 1988-2001

\begin{tabular}{lccc}
\hline Period & State sector $\mathbf{( \% )}$ & $\begin{array}{c}\text { Urban collective } \\
\text { enterprises } \mathbf{( \% )}\end{array}$ & $\begin{array}{c}\text { Nonpublic enter- } \\
\text { prises (\%) }\end{array}$ \\
\hline $1988-1989$ & 3.4 & 4.6 & 8.4 \\
$1990-1994$ & 4.3 & 4.1 & 9.4 \\
$1995-1999$ & 6.6 & 6.4 & 10.6 \\
$2000-2001$ & 8.8 & 8.0 & 11.6 \\
\hline
\end{tabular}


Table A.6: (Continued)

C.5. Advancement rates from one level to the next higher, China, 1980-1999

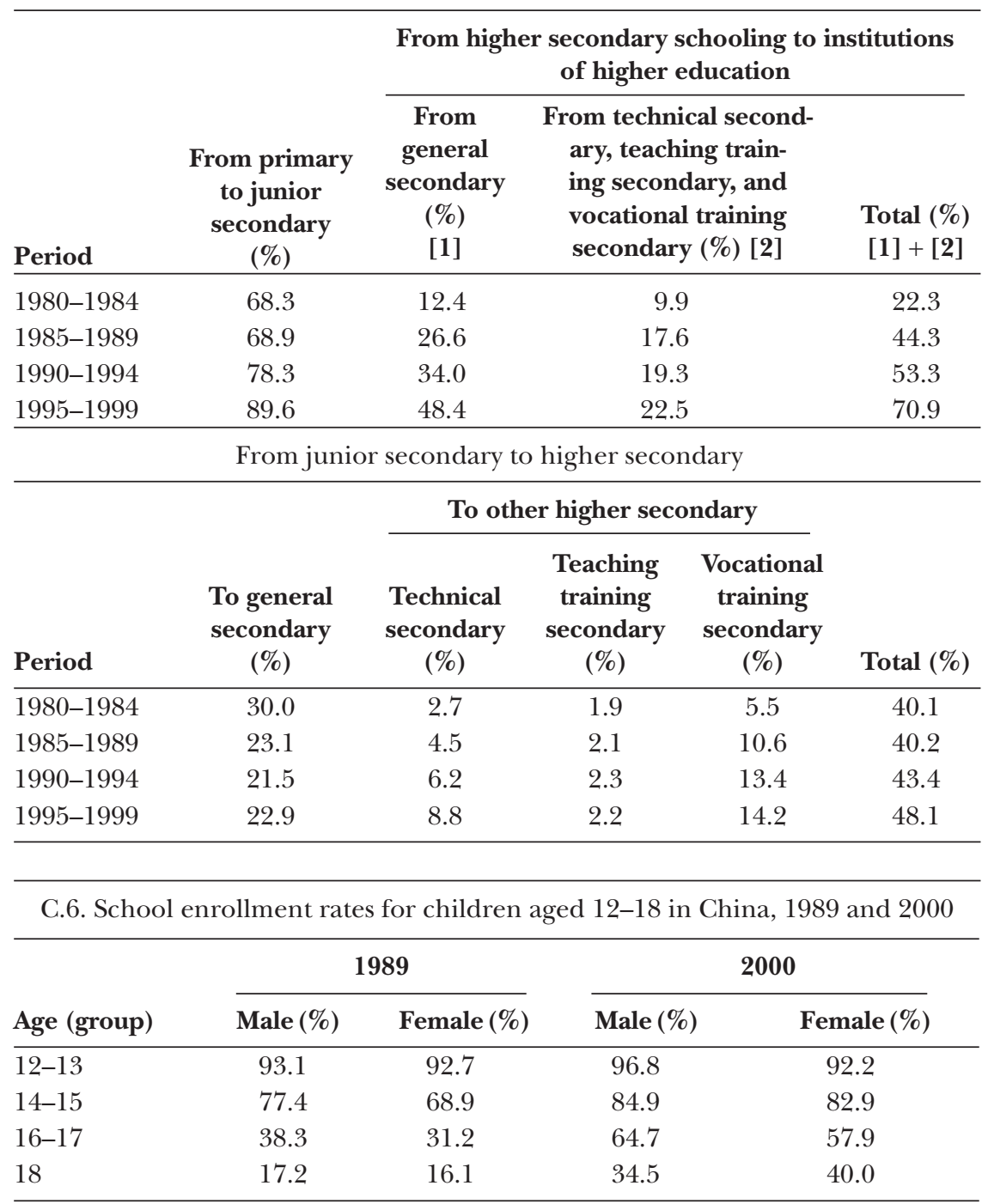


Table A.6: (Continued)

C.7. Growth in the number of teachers and the number of students in various types of schools, Japan, 1886-1940

\begin{tabular}{|c|c|c|c|c|c|c|}
\hline \multirow[b]{2}{*}{ Type of school } & \multicolumn{3}{|c|}{ Teachers $(\%)$} & \multicolumn{3}{|c|}{ Students (\%) } \\
\hline & $\begin{array}{l}1886- \\
1900\end{array}$ & $\begin{array}{l}1901- \\
1920\end{array}$ & $\begin{array}{c}1921- \\
1940\end{array}$ & $\begin{array}{l}1886- \\
1900\end{array}$ & $\begin{array}{c}1901- \\
1920\end{array}$ & $\begin{array}{c}1921- \\
1940\end{array}$ \\
\hline Elementary & 0.1 & 4.0 & 2.4 & 2.4 & 3.6 & 2.0 \\
\hline Middle (male) & 12.7 & 6.0 & 19.4 & 17.5 & 5.8 & 5.3 \\
\hline Middle (female) & 19.4 & 20.2 & 7.3 & 40.7 & 21.1 & 8.9 \\
\hline $\begin{array}{l}\text { High school } \\
\text { (male) }\end{array}$ & 28.7 & 1.3 & 8.7 & 18.1 & 2.2 & 6.2 \\
\hline University & 2.9 & 9.9 & 13.5 & 6.9 & 9.0 & 15.0 \\
\hline $\begin{array}{l}\text { Vocational } \\
\text { (regular) }\end{array}$ & 23.3 & 13.4 & 8.0 & 31.0 & 15.0 & 9.2 \\
\hline $\begin{array}{l}\text { Vocational } \\
\text { (continuance) }\end{array}$ & n.e. & 24.5 & 24.5 & n.e. & 59.9 & 6.3 \\
\hline
\end{tabular}

C.8. Estimates of the demand and supply of engineers in Japan, 1891-1940

\begin{tabular}{|c|c|c|c|c|}
\hline \multirow[b]{2}{*}{ Period } & \multicolumn{2}{|c|}{$\begin{array}{l}\text { Supply: Students of higher education } \\
\text { in science and engineering }\end{array}$} & \multirow[b]{2}{*}{$\begin{array}{c}\text { Estimated } \\
\text { growth in } \\
\text { demand a } \\
(\%)\end{array}$} & \multirow{2}{*}{$\begin{array}{l}\text { Estimated } \\
\text { demand } \\
\text { growth } \\
\text { minus sup- } \\
\text { ply growth } \\
(\%)\end{array}$} \\
\hline & $\begin{array}{c}\text { Percentage } \\
\text { of all higher } \\
\text { education } \\
\text { students }(\%)\end{array}$ & $\begin{array}{l}\text { Estimated growth } \\
\text { rate of graduates } \\
\text { in science and } \\
\text { engineering }(\%)\end{array}$ & & \\
\hline 1891-1895 & 15.8 & -13.7 & 20.5 & +43.2 \\
\hline 1896-1900 & 10.9 & 3.1 & 4.3 & +1.3 \\
\hline 1900-1905 & 7.7 & 12.1 & 14.4 & +2.4 \\
\hline 1906-1910 & 7.8 & 17.6 & 16.9 & -0.7 \\
\hline 1911-1915 & 10.2 & 11.5 & 13.3 & +1.7 \\
\hline 1916-1920 & 13.1 & 10.1 & 16.1 & -6.0 \\
\hline 1921-1925 & 14.2 & 17.3 & 11.4 & -5.9 \\
\hline 1926-1930 & 15.7 & 2.1 & 7.1 & +5.0 \\
\hline 1931-1935 & 11.8 & 8.3 & 6.1 & +2.2 \\
\hline 1936-1940 & 14.3 & 3.7 & 13.9 & +10.3 \\
\hline
\end{tabular}


Table A.6: (Continued)

C.9. Enrollment rate for compulsory schooling (COENR), and advancement rates: from upper secondary schools to high schools (HSAD); from high schools to universities (UNAD); from high schools to junior colleges (JCAD); and from high schools to universities or junior colleges (UNJCAD), Japan, 1950-2004

\begin{tabular}{|c|c|c|c|c|c|}
\hline \multirow[b]{2}{*}{ Period } & \multirow{2}{*}{$\begin{array}{c}\text { COENR } \\
(\%)\end{array}$} & \multicolumn{4}{|c|}{ Advancement rates $(\%)$} \\
\hline & & $\overline{\text { HSAD }}$ & UNAD & JCAD & UNJCAD \\
\hline 1950-1954 & 99.7 & 47.0 & 7.9 & 2.1 & 10.0 \\
\hline 1955-1959 & 99.8 & 52.7 & 8.3 & 2.1 & 10.4 \\
\hline 1960-1964 & 99.8 & 64.0 & 11.0 & 3.1 & 14.1 \\
\hline 1965-1969 & 99.8 & 74.7 & 13.3 & 5.0 & 18.3 \\
\hline 1970-1974 & 99.9 & 86.9 & 21.3 & 8.3 & 29.6 \\
\hline 1975-1979 & 99.9 & 93.0 & 26.8 & 11.3 & 38.1 \\
\hline 1980-1984 & 100.0 & 94.1 & 25.3 & 11.0 & 36.2 \\
\hline 1985-1989 & 100.0 & 93.9 & 24.9 & 11.4 & 36.3 \\
\hline 1990-1994 & 100.0 & 95.0 & 26.9 & 12.5 & 39.4 \\
\hline 1995-1999 & 100.0 & 95.9 & 35.0 & 12.2 & 47.2 \\
\hline 2000-1904 & 100.0 & 96.0 & 40.8 & 8.3 & 49.0 \\
\hline
\end{tabular}

${ }^{a}$ Growth in demand for engineers is based on combining growth in the number of employees in railroads and public utilities with the growth in prime mover horsepower installed in manufacturing.

n.e. $=$ not estimated.

Sources: Panel A.1 from p. 169 of Maddison (1998) and from pp. 281-282 of Ho (1959). Panel A.1 from p. 15 of Poston and Yaukey (1992) and from p. 138 of Wang and Mason (2008). Panel A.3 from p. 295 of Bramall (2009), from p. 228 of Poston and Yaukey (1992) and from p. 138 of Wang and Mason (2008). Panel A.4 from pp. 357-358 in Mosk (2008). Panel A.5 from p. 38 of Miyamoto (2004) and p. 357 in Mosk (2008). Panel A.6 from p. 296 in Mosk (2008). Panel B.1 from p. 366 in Mosk (2008). Panel C.1 from p. 63 in Maddison (1998). Panel C.2 from p. 188 in Bramell (2009). Panel C.3 from p. 186 in Cai et al. (2008). Panel C. 4 from p. 207 in Cai et al. (2008). Panel C.5 from p. 231 in Hannum et al. (2008). Panel C.6 from p. 236 in Hannum et al. (2008). Panel C.7 from p. 46-47 in Mosk (1995). Panel C.8 from p. 83 in Mosk (1995). Panel C.9 from Japan. Ministry of Internal Affairs and Communications and Statistical Research and Training Institute (2009).

was higher in pre-1940 Japan than it was in pre-1940 China, Japan's advantage in life expectancy stimulating an earlier expansion in the demand for higher education than was experienced in China; (6) reflecting Japan's earlier industrialization and Japan's earlier rise in per capita income compared to China - the biological standard of living and the human development index improved significantly in Japan, giving Japan a distinct advantage in withdrawing surplus labor from the agricultural sector; (7) in 
early 20th century Japan the spread of infectious diseases in densely packed urban environments drove up mortality levels in urbanized industrialized districts of Japan above those prevailing in agricultural communities but the diffusion of the germ theory of disease and associated public health and medical interventions reversed the relationship between urbanization and mortality risks by 1930 ; (8) in 1950 Japanese educational attainment far exceeded that prevailing in China but by 1992 the gap between the two countries had closed to a remarkable degree; and (9) the demand for engineers grew rapidly in pre-1940 Japan as the inorganic economy diffused throughout the land, supply growth tending to fall short of the surge in demand over most of the pre-1940 period.

Documenting labor supply and demand is the focus of Table A.7. Panels A.1 and A.2 speak to the rise in work days and hours worked in Japanese agriculture during the pre-1940 period. Panels A.3, A.4, and A.5 document the fact that surplus labor in pre-1940 Japan depressed wages in light manufacturing, particularly for females and specifically in the rapidly expanding textile sector, bolstering profits in that sector (while female agricultural wages exceeded those earned in manufacturing agricultural workers were not hired year around while manufacturing workers were so that it is likely actual earnings generated in the two sectors were approximately equal). Panel B.1 of the table speaks to the existence of redundant unutilized or underutilized labor in early 1930s China. Notable are the relatively high rates for unemployed or idle population in both agricultural and nonagricultural communities. Finally Panels A.6 and B.2 document the fact that labor productivity was relatively low in both Japan and China relative to labor productivity in other sectors - especially in manufacturing - substantiating the thesis advanced in this book about the crucial importance of withdrawing labor from farming, moving it into an industrial sector where it can contribute far more to national income. This last point speaks to the importance of structural shift in generating improvements in the index of total factor productivity appearing in Table A.1 and discussed in the Appendix to Chap. 2, Sec. 2.6.

The agricultural sector is analyzed in Table A.8. Panel A makes a crucial point: while the existence of surplus labor may not have posed a problem for the economic development of many countries - like the countries of settlement where population densities were low or even in India where the ratio of arable to total land area is high - it was a very pressing issue for Japan and China where population densities were and are high and the proportion of arable to total land area is low. Panels B.1-B.6 substantiate 
Table A.7: Labor force supply and demand in China and Japan, 1880-2004.

\section{A. Japan}

A.1. Workdays per worker (wdpw) and per male equivalent worker (wdpmew) in Japanese agriculture, 1880-1940

\begin{tabular}{lccccc}
\hline Item & $\mathbf{1 8 8 0}$ & $\mathbf{1 9 0 0}$ & $\mathbf{1 9 2 0}$ & $\mathbf{1 9 3 0}$ & $\mathbf{1 9 4 0}$ \\
\hline wdpw & 113 & 131 & 163 & 151 & 163 \\
wdpmew & 131 & 150 & 187 & 173 & 192 \\
\hline
\end{tabular}

A.2. Means and standard deviations for hours worked per worker unit (HPW) and for consumption per consumer unit (CPC) in Yen for farm households in Japan Surveyed in 1929: Classified by the ratio of consumer units to worker units $(\mathrm{C} / \mathrm{W})$ and by the number of worker units per cultivated land area (W/CL)

\begin{tabular}{lcccr}
\hline & \multicolumn{2}{c}{ HPW } & \multicolumn{2}{c}{ CPC } \\
\cline { 2 - 3 } Group & Mean & $\begin{array}{c}\text { Standard } \\
\text { deviation }\end{array}$ & Mean & $\begin{array}{r}\text { Standard } \\
\text { deviation }\end{array}$ \\
\hline & Classified by the C/W ratio & & \\
C/W $<1.1$ & 3020 & 988 & 267 & 107 \\
$1.1 \leq \mathrm{C} / \mathrm{W}<1.2$ & 3092 & 1127 & 230 & 69 \\
$1.2 \leq \mathrm{C} / \mathrm{W}<1.3$ & 2947 & 642 & 230 & 69 \\
$1.3 \leq \mathrm{C} / \mathrm{W}<1.4$ & 3177 & 977 & 204 & 57 \\
$1.4 \leq \mathrm{C} / \mathrm{W}<1.6$ & 3369 & 922 & 212 & 94 \\
$1.6 \leq \mathrm{C} / \mathrm{W}$ & 3650 & 1043 & 187 & 61 \\
All families & 3170 & 959 & 219 & 81 \\
& Classified by W/CL ratio & & \\
$\mathrm{W} / \mathrm{CL} \leq 0.015$ & 3329 & 1094 & 264 & 110 \\
$0.015 \leq \mathrm{W} / \mathrm{CL} \leq 0.02$ & 3296 & 905 & 213 & 68 \\
$0.02 \leq \mathrm{W} / \mathrm{CL} \leq 0.025$ & 3243 & 970 & 233 & 94 \\
$0.025 \leq \mathrm{W} / \mathrm{CL} \leq 0.03$ & 3203 & 983 & 215 & 67 \\
$0.03 \leq \mathrm{W} / \mathrm{CL} \leq 0.035$ & 2896 & 796 & 214 & 74 \\
$0.035 \leq \mathrm{W} / \mathrm{CL} \leq 0.04$ & 3299 & 1460 & 201 & 69 \\
$0.04 \leq \mathrm{W} / \mathrm{CL}$ & 2779 & 767 & 177 & 54 \\
\hline
\end{tabular}


Table A.7: $\quad$ (Continued)

A.3. Real daily wages: Nominal wages deflated by the consumer price index (CPI), 1934-1936 = 1, and wage differentials, Japan, 1885-1914

\begin{tabular}{|c|c|c|c|c|c|c|}
\hline \multirow[b]{3}{*}{ Period } & \multicolumn{4}{|c|}{ Real daily wages } & \multirow{2}{*}{\multicolumn{2}{|c|}{$\begin{array}{l}\text { Wage differential: manu- } \\
\text { facturing/agriculture }\end{array}$}} \\
\hline & \multicolumn{2}{|c|}{ Agriculture } & \multicolumn{2}{|c|}{ Manufacturing } & & \\
\hline & Males & Females & Males & Females & Males & Females \\
\hline 1885-1889 & 0.73 & 0.48 & 0.86 & 0.39 & 1.18 & 0.81 \\
\hline 1890-1894 & 0.87 & 0.59 & 0.80 & 0.40 & 0.92 & 0.68 \\
\hline 1895-1899 & 0.96 & 0.71 & 0.82 & 0.40 & 0.85 & 0.56 \\
\hline 1900-1904 & 0.91 & 0.70 & 0.91 & 0.42 & 1.00 & 0.60 \\
\hline 1905-1909 & 0.82 & 0.66 & 0.89 & 0.41 & 1.09 & 0.62 \\
\hline 1910-1914 & 0.88 & 0.67 & 0.90 & 0.44 & 1.02 & 0.66 \\
\hline
\end{tabular}

A.4. Nominal daily wages (Yen) deflated by price index for the sector $(1934-36=1)$, Japan, 1885-1914

\begin{tabular}{lccccc}
\hline & \multicolumn{2}{c}{ Agriculture } & & \multicolumn{2}{c}{ Manufacturing } \\
\cline { 2 - 3 } \cline { 5 - 6 } Period & Males & Females & & Males & Females \\
\hline $1885-1889$ & 0.65 & 0.42 & & 0.51 & 0.23 \\
$1890-1894$ & 0.67 & 0.45 & & 0.50 & 0.25 \\
$1895-1899$ & 0.75 & 0.55 & 0.54 & 0.26 \\
$1900-1904$ & 0.77 & 0.59 & & 0.62 & 0.28 \\
$1905-1909$ & 0.72 & 0.58 & & 0.60 & 0.33 \\
$1910-1914$ & 0.77 & 0.59 & 0.67 & 0.32 \\
\hline
\end{tabular}

A.5. Nominal daily wages $(w)$, nominal labor productivity $(q)$, and labor's share in value added $(S \%)$, Japan, 1895-1914: Cotton spinning and cotton weaving

\begin{tabular}{|c|c|c|c|c|c|c|c|c|}
\hline \multirow[b]{3}{*}{ Period } & \multicolumn{4}{|c|}{ Cotton spinning } & \multicolumn{4}{|c|}{ Cotton weaving } \\
\hline & \multicolumn{2}{|c|}{ Wages $(w)$} & \multirow[b]{2}{*}{$q$} & \multirow[b]{2}{*}{$S \%$} & \multicolumn{2}{|c|}{ Wages $(w)$} & \multirow[b]{2}{*}{$q$} & \multirow[b]{2}{*}{$S \%$} \\
\hline & Male & Female & & & Male & Female & & \\
\hline 1895-1899 & 0.22 & 0.14 & 0.63 & 25.7 & 0.24 & 0.13 & 1.53 & 9.8 \\
\hline 1900-1904 & 0.34 & 0.21 & 0.51 & 46.6 & 0.37 & 0.22 & 1.32 & 18.2 \\
\hline 1905-1909 & 0.43 & 0.26 & 0.92 & 32.1 & 0.44 & 0.27 & 1.06 & 27.6 \\
\hline 1910-1914 & 0.49 & 0.31 & 0.88 & 39.8 & 0.53 & 0.34 & 1.90 & 19.2 \\
\hline
\end{tabular}


Table A.7: (Continued)

A.6. Percentage shares of the labor force in three broad sectors of the economy $(\mathrm{P}=$ primary, $\mathrm{S}=$ secondary, and $\mathrm{T}=$ tertiary) and relative labor productivity in the sector (calculated as percentage of GDP in the sector divided by percentage of labor force in the sector, times 100), Japan, 1951-2000

\begin{tabular}{lccccccc}
\hline & \multicolumn{3}{c}{ Percentage of the labor force in: } & & \multicolumn{3}{c}{ Relative labor productivity in: } \\
\cline { 2 - 3 } Period & $\mathbf{P}$ & $\mathbf{S}$ & $\mathbf{T}$ & & $\mathbf{P}$ & $\mathbf{S}$ & T \\
\hline $1951-1955$ & 38.5 & 24.5 & 37.0 & & 47.9 & 141.3 & 126.8 \\
$1956-1960$ & 32.9 & 26.7 & 40.4 & & 45.2 & 142.0 & 117.0 \\
$1961-1965$ & 26.2 & 30.9 & 42.9 & & 40.5 & 132.6 & 112.9 \\
$1966-1970$ & 19.8 & 33.8 & 46.3 & & 39.1 & 121.4 & 110.5 \\
$1971-1975$ & 13.9 & 35.9 & 50.0 & & 38.9 & 115.6 & 106.4 \\
$1976-1980$ & 11.5 & 34.7 & 53.6 & & 38.7 & 109.5 & 107.4 \\
$1981-1985$ & 9.3 & 34.3 & 56.1 & & 34.8 & 107.1 & 107.0 \\
$1986-1990$ & 7.9 & 33.6 & 58.0 & & 33.2 & 106.6 & 106.0 \\
$1991-1995$ & 6.1 & 33.6 & 59.9 & & 32.8 & 97.1 & 109.1 \\
$1996-2000$ & 5.3 & 31.7 & 62.5 & & 28.4 & 91.7 & 111.0 \\
\hline
\end{tabular}

B. China

B.1. Percentage of population of China in agriculture and non-agriculture, 1933: Working, students, elderly or unemployed and idle

\begin{tabular}{lc}
\hline Category & $\begin{array}{c}\text { Percentage of total population } \\
\text { (or percentage of category if noted) }\end{array}$ \\
\hline Agricultural & Agricultural \\
Working in agriculture & 73.00 \\
Working only in agriculture & 42.46 \\
Children under age 7 & 23.76 \\
Students & 14.24 \\
Persons over age 65 & 1.02 \\
Unemployed or idle & 2.20 \\
& Non-agricultural \\
Working ages 7-64 & \\
Working in factories & 27.0 \\
Working in handicrafts & 0.2 \\
Children under age 7 & 2.4 \\
Students age 7 and over & 5.3 \\
Unemployed or idle & 1.15 \\
& 10.39 (38.48\% of non-agricultural \\
& population) \\
\hline
\end{tabular}


Table A.7: (Continued)

B.2. Percentage of China's labor force in three broad sectors of the economy $(\mathrm{A}=$ agriculture or primary, $\mathrm{I}=$ industry or secondary, and $\mathrm{S}=$ services or tertiary) and relative labor productivity in the sector, $1952-2000^{\mathrm{a}}$

Percentage of the Labor Force in:

\begin{tabular}{lcrrrrrr}
\cline { 7 - 8 } Year & $\mathbf{A}$ & $\mathbf{I}$ & $\mathbf{S}$ & & $\mathbf{A}$ & $\mathbf{I}$ & $\mathbf{S}$ \\
\hline 1952 & 84.0 & 7.0 & 9.0 & & 59.5 & 300.0 & 322.2 \\
1970 & 81.0 & 10.0 & 9.0 & & 49.4 & 460.0 & 144.4 \\
1980 & 69.0 & 18.0 & 13.0 & & 43.5 & 272.2 & 161.5 \\
1985 & 62.0 & 21.0 & 17.0 & & 45.2 & 204.8 & 170.6 \\
1990 & 60.0 & 21.0 & 19.0 & & 45.0 & 200.0 & 163.2 \\
1995 & 52.0 & 23.0 & 25.0 & 38.5 & 213.0 & 124.0 \\
2000 & 50.0 & 51.0 & 27.5 & 32.0 & 226.7 & 120.0 \\
\hline
\end{tabular}

B.3. Percentage of employed labor force in china in primary $(\mathrm{P})$, secondary $(\mathrm{S})$ and tertiary $(\mathrm{T})$ sectors of the economy; percentage of the employed labor force that is urban $(\mathrm{U})$ or rural $(\mathrm{R})$; and percentage of the employed urban labor force in state owned enterprises (USOE), 1978-2004

\begin{tabular}{lcccccc}
\hline & \multicolumn{9}{c}{ Percentage of the employed labor force in: } & \multirow{2}{*}{$\begin{array}{c}\text { SOE \% of urban } \\
\text { Period }\end{array}$} & P & S & T & U & R & - \\
\hline $1978-1989$ & 70.2 & 17.5 & 12.4 & - & - & - \\
$1980-1984$ & 67.2 & 18.5 & 14.3 & - & - & - \\
$1985-1989$ & 60.5 & 21.8 & 17.7 & - & - & 60.5 \\
$1990-1994$ & 57.8 & 21.9 & 20.3 & 27.0 & 73.0 & 49.7 \\
$1995-1999$ & 50.5 & 23.3 & 26.2 & 29.7 & 70.3 & 29.6 \\
$2000-2004$ & 49.2 & 22.1 & 28.7 & 33.6 & 66.4 & - \\
\hline
\end{tabular}

Notes: See the heading in Panel A.6 above for the method of computing labor productivity in the sectors. Basically the A sector in Panel B.2 corresponds to the P sector in Panel A.6; the I sector in Panel B.2 corresponds to the S sector in Panel A.6; and the S sector in Panel B.2 corresponds to the T sector in Panel A.6. However these correspondences may not be exact.

Sources: Panel A.1 from p. 61 of Mosk (1995). Panel A.2 from various tables in Mosk (1983). Panels A.3 - A.5 from p. 113 in Mosk (2008). Panel A.6 from p. 359 in Mosk (2008). Panel B.1 from pp. 10-11 in Feuerwerker (1977). Panel B.2 from p. 272 in Bramall (2009) and p. 482 of Huang et al. (2008). Panel B.3 from p. 168 in Cai et al. (2008). 
Table A.8: Agriculture in China and Japan, 1400-2006.

A. Land use patterns, circa 1993

\begin{tabular}{|c|c|c|c|c|c|}
\hline Country & $\begin{array}{l}\text { Land area } \\
\text { (000 ha) }\end{array}$ & $\begin{array}{c}\text { Arable land \&c } \\
\text { permanent } \\
\text { crop area }\end{array}$ & $\begin{array}{l}\text { Proportion } \\
\text { arable }(\%)\end{array}$ & $\begin{array}{l}\text { Population } \\
\quad(000 s)\end{array}$ & $\begin{array}{l}\text { Arable land } \\
\text { per head of } \\
\text { population }\end{array}$ \\
\hline \multicolumn{6}{|c|}{ A.1. Eurasian regions with long-standing settled agriculture } \\
\hline China & 959,696 & 95,975 & 10.0 & $1,178,440$ & 0.08 \\
\hline Europe & 487,696 & 135,705 & 27.8 & 506,910 & 0.26 \\
\hline India & 328,759 & 169,650 & 51.6 & 899,000 & 0.19 \\
\hline Japan & 37,780 & 4463 & 11.8 & 124,753 & 0.04 \\
\hline \multicolumn{6}{|c|}{ A.2. Countries of settlement } \\
\hline $\begin{array}{l}\text { United } \\
\text { States }\end{array}$ & 980,943 & 187,776 & 19.1 & 293,172 & 0.73 \\
\hline Canada & 997,614 & 45,500 & 4.6 & 28,386 & 1.58 \\
\hline Australia & 771,336 & 46,486 & 6.0 & 17,769 & 2.62 \\
\hline Brazil & 851,197 & 48,955 & 5.8 & 158,913 & 0.31 \\
\hline
\end{tabular}

B. Agriculture in Japan, 1910-2004

B.1. Indices $(1960-1964=100)$

\begin{tabular}{|c|c|c|c|c|c|}
\hline Period & $\begin{array}{c}\text { Arable } \\
\text { land area } \\
\text { (IALA) }\end{array}$ & $\begin{array}{c}\text { Paddy fields } \\
\text { actually } \\
\text { planted (IPP) }\end{array}$ & $\begin{array}{c}\text { Farm } \\
\text { households } \\
(\text { IFH })\end{array}$ & $\begin{array}{c}\text { Adult farm } \\
\text { household } \\
\text { members fully } \\
\text { engaged in } \\
\text { farming (IFW) } \\
\text { a }\end{array}$ & $\begin{array}{c}\text { Rice } \\
\text { output } \\
\text { (IRO) }\end{array}$ \\
\hline $\begin{array}{l}1910- \\
1919\end{array}$ & 95.9 & 91.8 & 93.1 & n.e. & 63.6 \\
\hline $\begin{array}{l}1920- \\
1929\end{array}$ & 98.5 & 95.3 & 93.3 & n.e. & 69.5 \\
\hline $\begin{array}{l}1930- \\
1939\end{array}$ & 98.6 & 97.0 & 94.0 & n.e. & 74.3 \\
\hline $\begin{array}{l}1940- \\
1944\end{array}$ & 95.8 & 94.3 & n.e. & n.e. & 71.7 \\
\hline $\begin{array}{l}1955- \\
1959\end{array}$ & 96.7 & 98.9 & n.e. & n.e. & 93.0 \\
\hline $\begin{array}{l}1960- \\
1964\end{array}$ & 100.0 & 100.0 & 100.0 & 100.0 & 100.0 \\
\hline
\end{tabular}


Table A.8: (Continued)

\begin{tabular}{|c|c|c|c|c|c|}
\hline $\begin{array}{l}1965- \\
1969\end{array}$ & 97.8 & 99.4 & 93.4 & 79.2 & 106.9 \\
\hline $\begin{array}{l}1970- \\
1974\end{array}$ & 93.9 & 82.8 & 89.1 & 66.3 & 94.1 \\
\hline $\begin{array}{l}1975- \\
1979\end{array}$ & 90.9 & 81.2 & 82.9 & 55.5 & 98.3 \\
\hline $\begin{array}{l}1980- \\
1984\end{array}$ & 89.4 & 70.0 & 78.2 & 51.6 & 82.5 \\
\hline $\begin{array}{l}1985- \\
1989\end{array}$ & 87.9 & 67.0 & 73.4 & 49.9 & 85.1 \\
\hline $\begin{array}{l}1990- \\
1994\end{array}$ & 85.1 & 64.4 & 49.4 & 38.2 & 79.3 \\
\hline $\begin{array}{l}1995- \\
1999\end{array}$ & 81.6 & 58.7 & 43.9 & 32.6 & 77.3 \\
\hline $\begin{array}{l}2000- \\
2004\end{array}$ & 78.6 & 51.9 & 38.5 & 31.3 & 69.0 \\
\hline
\end{tabular}

B.2. Relative indices, percentage of arable land in paddy (ALP\%) and adult farm household members fully engaged in farming per farm household (FWPFH)

\begin{tabular}{lccccc}
\hline & \multicolumn{2}{c}{ Relative indices (in rice production) } & & \\
\cline { 2 - 4 } & $\begin{array}{c}\text { Land } \\
\text { productivity } \\
\text { Period }\end{array}$ & $\begin{array}{c}\text { Farm } \\
\text { (IRO)/IPP) } \\
\text { productivity } \\
\text { (IRO/IFH) }\end{array}$ & $\begin{array}{c}\text { Adult farm } \\
\text { worker } \\
\text { productivity } \\
\text { (IRO/IFW) }\end{array}$ & ALP\% & FWPH \\
\hline $1910-1919$ & 69.3 & 68.0 & n.e. & 50.5 & n.e. \\
$1920-1929$ & 72.8 & 73.0 & n.e. & 51.1 & n.e. \\
$1930-1939$ & 76.6 & 77.7 & n.e. & 53.8 & n.e. \\
$1940-1944$ & n.e. & n.e. & n.e. & 53.9 & n.e. \\
$1955-1959$ & n.e. & n.e. & n.e. & 55.3 & n.e. \\
$1960-1964$ & 100.0 & 100.0 & 100.8 & 55.9 & 1.9 \\
$1965-1969$ & 107.5 & 114.6 & 135.6 & 57.5 & 1.6 \\
$1970-1974$ & 113.7 & 105.7 & 143.1 & 58.2 & 1.4 \\
$1975-1979$ & 121.1 & 118.6 & 177.3 & 56.7 & 1.3 \\
$1980-1984$ & 117.9 & 105.6 & 160.1 & 55.5 & 1.3 \\
$1985-1989$ & 127.1 & 116.0 & 170.5 & 54.6 & 1.3 \\
$1990-1994$ & 123.0 & 160.8 & 209.3 & 54.3 & 1.5 \\
$1995-1999$ & 131.8 & 176.0 & 237.1 & 54.6 & 1.4 \\
$2000-2004$ & 132.8 & 179.3 & 220.5 & 54.7 & 1.6 \\
\hline
\end{tabular}


Table A.8: (Continued)

B.3. Percentage growth rate for inputs (labor)

\begin{tabular}{lccccc}
\hline & \multicolumn{2}{c}{ Number of workers } & & \multicolumn{2}{c}{ Workdays } \\
\cline { 2 - 3 } \cline { 5 - 6 } Period & Male & Female & & Total & Per worker \\
\hline $1935-1945$ & -1.7 & 2.0 & & -0.9 & -1.0 \\
$1945-1955$ & 1.5 & 0.3 & & 1.3 & 0.4 \\
$1955-1965$ & -3.5 & -2.5 & & -2.7 & 0.3 \\
\hline
\end{tabular}

B.4. Percentage growth for inputs (variable and fixed capital)

\begin{tabular}{|c|c|c|c|c|c|c|}
\hline \multirow[b]{2}{*}{ Period } & \multicolumn{3}{|c|}{ Fixed capital } & \multicolumn{3}{|c|}{$\begin{array}{l}\text { Variable capital (current } \\
\text { inputs) }\end{array}$} \\
\hline & \multicolumn{2}{|c|}{$\begin{array}{l}\text { Machinery and } \\
\text { implements }\end{array}$} & Total & Fertilizers & \multicolumn{2}{|c|}{ Total } \\
\hline $1935-1945$ & \multicolumn{2}{|c|}{-0.2} & -1.4 & -5.0 & \multicolumn{2}{|c|}{-6.6} \\
\hline $1945-1955$ & \multicolumn{2}{|r|}{3.1} & 2.0 & 13.5 & \multicolumn{2}{|c|}{15.0} \\
\hline $1955-1965$ & \multicolumn{2}{|c|}{11.5} & 7.8 & 3.6 & \multicolumn{2}{|c|}{8.5} \\
\hline \multicolumn{7}{|c|}{$\begin{array}{l}\text { B.5. Percentage growth rates of relative prices for inputs relative to agricultural } \\
\text { output price }\end{array}$} \\
\hline & \multicolumn{2}{|c|}{ Labor and land } & \multicolumn{2}{|c|}{ Fixed capital } & \multicolumn{2}{|c|}{$\begin{array}{l}\text { Variable capital } \\
\text { (current inputs) }\end{array}$} \\
\hline Period & $\begin{array}{l}\text { Labor } \\
\text { wages }\end{array}$ & $\begin{array}{l}\text { Cultivated } \\
\text { land prices }\end{array}$ & $\begin{array}{l}\text { Machinery and } \\
\text { implements }\end{array}$ & Total & Fertilizer & Total \\
\hline $1920-1930$ & 1.9 & 2.9 & 0.3 & 1.3 & -1.7 & -1.2 \\
\hline $1955-1965$ & 6.1 & 4.3 & -3.2 & -0.9 & -5.0 & -4.5 \\
\hline $1960-1970$ & 7.2 & -1.1 & -7.1 & -1.1 & -5.4 & -5.0 \\
\hline
\end{tabular}

(Continued) 
Table A.8: (Continued)

B.6. Percentage growth rates of productivities of labor and land

\begin{tabular}{|c|c|c|c|c|c|c|}
\hline \multirow[b]{2}{*}{ Period } & \multicolumn{2}{|c|}{ Labor productivity } & \multicolumn{2}{|c|}{ Land productivity } & \multicolumn{2}{|c|}{$\begin{array}{l}\text { Relative contribu- } \\
\text { tion to labor pro- } \\
\text { ductivity growth } \\
\text { of land productiv- } \\
\text { ity growth }(\%)\end{array}$} \\
\hline & $\begin{array}{c}\text { Per male } \\
\text { equiva- } \\
\text { lent } \\
(1)\end{array}$ & $\begin{array}{l}\text { Per work- } \\
\text { day } \\
(2)\end{array}$ & $\begin{array}{c}\text { Per } \\
\text { paddy-field } \\
\text { equivalent } \\
\text { (3) }\end{array}$ & $\begin{array}{c}\text { Per } \\
\text { hectare } \\
\text { of crop } \\
\text { area (4) }\end{array}$ & $(3) /(1)$ & $(4) /(2)$ \\
\hline $\begin{array}{l}1935- \\
1945\end{array}$ & -1.7 & -0.9 & -1.5 & -0.7 & 88 & 78 \\
\hline $\begin{array}{l}1945- \\
1955\end{array}$ & 2.2 & 1.9 & 2.9 & 2.1 & 132 & 111 \\
\hline $\begin{array}{l}1955- \\
1965\end{array}$ & 6.9 & 6.5 & 3.4 & 4.3 & 49 & 66 \\
\hline
\end{tabular}

C. Agriculture in China, 1400-2006

C.1. Growth accounting for growth in china's grain output, 1400-1957 (assuming a constant level of per capita grain consumption)

\begin{tabular}{|c|c|c|c|c|c|c|}
\hline \multirow[b]{2}{*}{ Period } & \multicolumn{5}{|c|}{ Annual compound growth rates (\%) } & \multirow{2}{*}{$\begin{array}{l}\text { Share of } \\
\text { total factor } \\
\text { productivity }\end{array}$} \\
\hline & Output & Labor & Land & Capital & $\begin{array}{l}\text { Total factor } \\
\text { productivity }\end{array}$ & \\
\hline $1400-1770$ & 0.32 & 0.19 & 0.05 & 0.06 & 0.01 & 4 \\
\hline $1700-1850$ & 0.59 & 0.35 & 0.06 & 0.05 & 0.12 & 21 \\
\hline $1850-1957$ & 0.45 & 0.27 & 0.06 & 0.07 & 0.04 & 10 \\
\hline
\end{tabular}

C.2. Indices $(1950-1954=100)$ for agricultural output and grain consumption, $1950-1978$

\begin{tabular}{|c|c|c|c|}
\hline Item & $1950-1956$ & $1957-1963$ & 1964-1978 \\
\hline \multicolumn{4}{|c|}{ Sown area } \\
\hline Grain & 102.5 & 100.8 & 98.2 \\
\hline Cotton & 105.1 & 94.8 & 97.0 \\
\hline
\end{tabular}


Table A.8: (Continued)

\begin{tabular}{|c|c|c|c|c|c|}
\hline \multicolumn{6}{|c|}{ Yield per hectare } \\
\hline Grain & \multicolumn{2}{|c|}{103.5} & \multicolumn{2}{|l|}{106.3} & 160.7 \\
\hline Cotton & \multicolumn{2}{|l|}{105.6} & \multicolumn{2}{|l|}{125.6} & 217.1 \\
\hline \multicolumn{6}{|c|}{ Grain output, population, and per capita output } \\
\hline Grain output & 106.4 & & 107.3 & & 157.8 \\
\hline Population $^{\mathrm{b}}$ & 102.3 & & 116.1 & & 146.5 \\
\hline Per capita output & 103.8 & & 92.6 & & 107.3 \\
\hline \multicolumn{6}{|c|}{ C.3. Value added (in 1987 Yuan) } \\
\hline Item & 1933 & 1952 & 1957 & 1978 & 1995 \\
\hline Per head & 277 & 225 & 241 & 235 & 439 \\
\hline Per worker & 789 & 748 & 812 & 781 & 1591 \\
\hline Per hectare cultivated & 1353 & 1185 & 1374 & 2265 & 5563 \\
\hline
\end{tabular}

C.4 Indices $(1955=100)$ for fertilizer output, fertilizer consumption, and fertilizer imports (Tons)

\begin{tabular}{lccc}
\hline Item & $\mathbf{1 9 5 5 - 1 9 5 9}$ & $\mathbf{1 9 6 0 - 1 9 6 4}$ & $\mathbf{1 9 6 5 - 1 9 6 6}$ \\
\hline Output & 286.9 & 690.1 & 1345.6 \\
Consumption & 172.4 & 306.8 & 617.5 \\
Imports & 127.5 & 156.8 & 332.6 \\
\hline
\end{tabular}

C.5. Growth rates for value added and tons of grain produced

\begin{tabular}{|c|c|c|c|c|}
\hline \multirow[b]{2}{*}{ Period } & \multicolumn{2}{|c|}{ Value added (1980 prices) } & \multirow{2}{*}{$\begin{array}{l}\text { Value added } \\
\text { (comparable } \\
\text { prices) }(\%)\end{array}$} & \multirow{2}{*}{$\begin{array}{c}\text { Tons of grain } \\
(\%)\end{array}$} \\
\hline & Farming $(\%)$ & Agriculture(\%) & & \\
\hline \multicolumn{5}{|c|}{ Collective farming } \\
\hline 1955-1981 & 2.8 & 3.2 & 2.6 & 2.8 \\
\hline 1963-1981 & 3.3 & 3.6 & 2.9 & 3.5 \\
\hline \multicolumn{5}{|c|}{ Family farming } \\
\hline 1981-2006 & 4.5 & 5.6 & 4.2 & 1.3 \\
\hline 1984-2006 & 4.3 & 5.5 & 3.9 & 1.0 \\
\hline
\end{tabular}


Table A.8: (Continued)

C.6. Growth rates of farm output, input, and total factor productivity

\begin{tabular}{lcccc}
\hline Item & $\mathbf{1 9 5 2 - 1 9 5 7}$ & $\mathbf{1 9 5 7 - 1 9 7 8}$ & $\mathbf{1 9 7 8 - 1 9 8 7}$ & $\mathbf{1 9 8 7 - 1 9 9 4}$ \\
\hline Gross farm output & 3.70 & 2.32 & 5.77 & 4.28 \\
Farm gross value added & 3.05 & 1.72 & 5.52 & 3.62 \\
Farm inputs & 6.36 & 2.54 & 4.35 & 4.83 \\
Non-farm inputs & 12.12 & 8.98 & 8.43 & 6.67 \\
Farm employment & 1.35 & 1.92 & 0.49 & 0.58 \\
Farm labor productivity & 1.66 & -0.19 & 4.99 & 3.05 \\
Irrigated area cultivated & 6.46 & 2.41 & -0.16 & 1.32 \\
Non-irrigated land & -0.79 & -2.08 & -0.6 & -1.49 \\
cultivated & & & & \\
Augmented land & 1.79 & 0.18 & -0.32 & 0.34 \\
Other capital & 7.81 & 4.43 & 5.00 & 3.48 \\
Total factor productivity & 0.63 & 0.57 & 4.56 & 2.67 \\
\hline
\end{tabular}

C.7. Indices for industrial inputs into China's rural economy $(1965=100)$

\begin{tabular}{lccc}
\hline Item & $\mathbf{1 9 6 2 - 1 9 6 4}$ & $\mathbf{1 9 7 0 - 1 9 7 4}$ & $\mathbf{1 9 7 5 - 1 9 7 8}$ \\
\hline Kilowatts of power & 64.6 & 300.0 & 646.9 \\
Millions of tons of chemical fertilizer & 54.8 & 264.0 & 399.6 \\
Cement (millions of tons) & 37.7 & 311.1 & 575.9 \\
Irrigation/drainage equipment & 69.2 & 270.0 & 572.1 \\
tractors & 75.8 & 328.2 & 704.6 \\
Power tillers & n.e & 273.3 & 1222.2 \\
Total horsepower per cultivated & 76.7 & 310.0 & 692.5 \\
hectare & & &
\end{tabular}

C.8. Growth rates for agricultural GDP and value added produced in various sub-sectors of agriculture, 1970-2000

Reform period

\begin{tabular}{lcccc}
\cline { 3 - 5 } Item & $\mathbf{1 9 7 0 - 1 9 7 8}$ & $\mathbf{1 9 7 8 - 1 9 8 4}$ & $\mathbf{1 9 8 5 - 1 9 9 5}$ & $\mathbf{1 9 9 6 - 2 0 0 0}$ \\
\hline GDP & 4.9 & 8.8 & 3.8 & 4.2 \\
Grain & 2.8 & 4.7 & 1.7 & 0.03 \\
Rice & 2.5 & 4.5 & 0.6 & 0.3 \\
Wheat & 7.0 & 8.3 & 1.9 & -0.4 \\
\hline & & & & (Continued)
\end{tabular}


Table A.8: (Continued)

\begin{tabular}{lrrrr}
\hline $\begin{array}{l}\text { Total cash crop } \\
\text { area sown }\end{array}$ & 2.4 & 5.1 & 2.1 & -0.4 \\
$\begin{array}{l}\text { Cotton } \\
\text { Meat (pork, beef, }\end{array}$ & -0.4 & 19.3 & -0.3 & -1.9 \\
$\begin{array}{l}\text { poultry) } \\
\text { Fishery }\end{array}$ & 5.4 & 9.1 & 8.8 & 6.5 \\
\hline
\end{tabular}

${ }^{a}$ Farm household members aged 15 and over who work full time in farm production.

$\mathrm{b}$ The population estimates used here are those appearing in Maddison (2006: p. 292).

n.e. $=$ not estimated.

Sources: Panel A data from p. 28 of Maddison (1998). Panels B.1 and B.2 data from various tables in Japan. Ministry of Internal Affairs and Communications and Statistical Research and Training Institute (2009). Panels B.3-B.6 data from p. 248-249 in Mosk (2008). Panels C.1 and C. 4 from p. 74 and p. 82 in Perkins (1969). Panels C.2 and C. 8 from p. 472 and p. 479 in Huang et al.(2008). Panels C.3 and C.6 from p. 71 and p. 75 in Maddison (1998). Panel C.5 from p. 228 in Bramall (2009). Panel C.7 from pp. 80-81 in Rawski (1979).

points made in Chap. 2 concerning the role of relative factor scarcities in shaping the nature of technological progress in Japanese agriculture, land augmentation achieved through use of fertilizer (coupled with the diffusion of enhanced seed varieties and better management of irrigation) preceding mechanization of agricultural tasks. In particular Panel B.5 points to the importance of relative prices in a basically market oriented economy for this process. Panels C.1 and C.3 provide estimates of pre-1950 Chinese agriculture. The pre-1950 estimates suggest that total factor productivity growth was on-going in Chinese farming throughout the period 1400-1957 but was proceeding at a relatively slow pace. This coupled with growth in land and capital permitted population to grow albeit with fits and starts, decline occurring in some periods (for instance in the two decades after 1850). Panel C.2 suggests that this pattern continued through 1963, being slightly mitigated between 1964 and 1978 when output per capita actually improved somewhat. Panels C.4 and C.6 speak to the importance of land augmentation in Chinese agriculture during the period 1952-1978, especially to the importance of fertilizer and irrigation for expanding output. Panel C.5 suggests that collective farming failed to generate growth rates for farm value added achieved by family farming in the aftermath of the reforms dismantling collectivization begun in the late 1970s. Panel C.7 documents the growing use of machinery in Chinese farming, especially in the three years leading up to the onset of the reform program commenced in 1978. And Panel C.8 speaks to the importance of the breaking up of the 
Table A.9: Expansion of infrastructure and industry in China and Japan, 1880-2000.

A. The penetration of infrastructure, China and Japan compared, circa 1920 and $2000^{\mathrm{a}}$

\begin{tabular}{|c|c|c|c|c|c|c|c|}
\hline \multirow[b]{2}{*}{ Item } & \multicolumn{2}{|c|}{ Road length (km) } & \multicolumn{4}{|c|}{ Railroads } & \multirow[b]{2}{*}{$\begin{array}{l}\text { Electric- } \\
\text { ity gener- } \\
\text { ated } \\
(\mathbf{k w ~ h})\end{array}$} \\
\hline & Total & Paved & $\begin{array}{l}\text { Track } \\
(\mathbf{k m})\end{array}$ & $\begin{array}{l}\text { Oper- } \\
\text { ation- } \\
(\mathbf{k m})\end{array}$ & $\begin{array}{c}\text { Freight } \\
\text { volume } \\
\text { (ton- } \\
\text { km) }\end{array}$ & $\begin{array}{c}\text { Pas- } \\
\text { senger } \\
\text { traffic } \\
\text { (passen- } \\
\text { ger-km) }\end{array}$ & \\
\hline \multicolumn{8}{|c|}{ Per person } \\
\hline $\begin{array}{l}\text { China, } \\
1920\end{array}$ & n.e. & 0.00006 & 0.00002 & n.e. & 15.5 & 8.6 & n.e. \\
\hline $\begin{array}{l}\text { China, } \\
2000\end{array}$ & n.e. & 0.02 & 0.00004 & n.e. & 11,822 & 355.4 & 971.7 \\
\hline $\begin{array}{l}\text { Japan, } \\
1920\end{array}$ & 15.8 & n.e. & 0.24 & 0.28 & 177.5 & 32.1 & 913.3 \\
\hline $\begin{array}{l}\text { Japan, } \\
2000\end{array}$ & 9.2 & 7.0 & 0.19 & 0.22 & 174,401 & 170.6 & 8599.5 \\
\hline \multicolumn{8}{|c|}{ Per land area (Per hectare) } \\
\hline $\begin{array}{l}\text { China, } \\
1920\end{array}$ & n.e. & 0.00003 & 0.00001 & n.e. & 7.7 & 4.3 & n.e. \\
\hline $\begin{array}{l}\text { China, } \\
2000\end{array}$ & n.e. & 0.02 & 0.00006 & n.e. & 15,711 & 472.3 & 1291.4 \\
\hline $\begin{array}{l}\text { Japan, } \\
1920\end{array}$ & 23.4 & n.e. & 0.36 & 0.42 & 262.9 & 47.5 & 1352.9 \\
\hline $\begin{array}{l}\text { Japan, } \\
2000\end{array}$ & 30.9 & 23.6 & 0.65 & 0.73 & 585,919 & 573.0 & 28891.0 \\
\hline
\end{tabular}

B. Infrastructure and industry in Japan, 1880-1985

B.1. The expansion of railroads and the disappearance of traditional transportation in Japan (Rikusha and Small Boats, Kobune), indices with 1920-1921 $=100^{\mathrm{b}}$

\begin{tabular}{lccccccc}
\hline & \multicolumn{3}{c}{ Railroads (operation-km) } & & \multicolumn{2}{c}{ Traditional transport } \\
\cline { 2 - 3 } Period & National & Regional & Street & Total & & Rikusha & Kobune \\
\hline $1900-1909$ & 35.6 & 104.4 & n.e. & 45.1 & & 162.6 & 266.6 \\
$1910-1919$ & 85.1 & 66.7 & 92.5 & 78.6 & & 111.9 & 168.2 \\
$1920-1929$ & 115.9 & 141.8 & 113.2 & 120.9 & & 70.5 & 86.8 \\
$1930-1941$ & 159.4 & 207.4 & 109.1 & 162.6 & & 23.3 & 77.5 \\
\hline
\end{tabular}


Table A.9: $\quad$ (Continued)

B.2. Electricity generated (GEN), electric lights (LIGHT), wattage in lights (WATT), and electrified cars on railroads (CAR): Indices with 1920-1921 $=100$

\begin{tabular}{lrrrr}
\hline Period & GEN & LIGHT & WATT & CAR \\
\hline $1910-1914$ & 30.4 & 30.0 & 47.8 & 46.1 \\
$1925-1929$ & 143.4 & 232.0 & 247.2 & 179.9 \\
$1935-1939$ & 724.2 & 555.0 & 732.2 & 190.4 \\
\hline
\end{tabular}

B.3. Number of electric lights (LIGHT) and electricity supplied (ELEC): Indices with 1920-1921 = 100 for Japan and the Tokaido industrial belt (INB) and the percentage for the Tokaido industrial belt $(\mathrm{INB} \%)^{\mathrm{c}}$

\begin{tabular}{lrrrrrrr}
\hline & \multicolumn{3}{c}{ LIGHT } & & \multicolumn{3}{c}{ ELEC } \\
\cline { 2 - 4 } Period & Japan & INB & INB\% & & Japan & INB & INB\% \\
\hline $1910-1919$ & 41.7 & 51.4 & 65.2 & & 70.4 & 74.7 & 45.3 \\
$1930-1937$ & 163.1 & 160.4 & 40.2 & & 339.6 & 386.7 & 48.9 \\
\hline
\end{tabular}

B.4. Powered factories as a percentage classified by number of workers in factories (POW\%) and composition of inanimate power sources for manufacturing: STEAM (steam engines and turbines), (INCOM) internal combustion engines, and electric motors (ELEC)

\begin{tabular}{|c|c|c|c|c|c|c|c|}
\hline \multicolumn{4}{|c|}{ POW\% classified by number of workers } & \multicolumn{4}{|c|}{ Composition of power sources } \\
\hline Year & 5-29 & 30-99 & $\begin{array}{l}100 \text { and } \\
\text { over }\end{array}$ & Year & STEAM & INCOM & ELEC \\
\hline 1909 & 20.5 & 69.7 & 88.4 & 1910 & 80.6 & 6.6 & 21.8 \\
\hline 1919 & 54.3 & 88.6 & 99.3 & 1920 & 31.3 & 3.4 & 58.9 \\
\hline 1930 & 80.1 & 95.3 & 99.6 & 1930 & 15.6 & 1.2 & 81.8 \\
\hline
\end{tabular}

B.5. The expansion of transportation, 1955-1970: Indices for transportation flows with $1965=100$

\begin{tabular}{rrrrrrrrr}
\hline & \multicolumn{4}{c}{ Cargo } & \multicolumn{4}{c}{ Passenger } \\
\cline { 2 - 9 } Year & Total & Rail & $\begin{array}{c}\text { Motor } \\
\text { vehicle }\end{array}$ & Sea & Total & Rail & $\begin{array}{r}\text { Motor } \\
\text { vehicle }\end{array}$ & Bus \\
\hline 1955 & 31.5 & 73.1 & 19.8 & 35.7 & 31.0 & 54.7 & 16.6 & 30.9 \\
1970 & 262.1 & 109.4 & 286.4 & 179.6 & 313.7 & 122.1 & 396.3 & 113.1 \\
\hline
\end{tabular}


Table A.9: $\quad$ (Continued)

B.6. Index for the price of transport (TRANSPI) relative to the consumer price index (CPI): 1880-1939 and 1955-1985

\begin{tabular}{lccc}
\hline Period & CPI (1) & TRANSPI (2) & $\begin{array}{c}\text { Relative cost of } \\
\text { transport: (2)/(1) }\end{array}$ \\
\hline \multirow{4}{*}{ 1880-1899 } & Pre-1940: Indices with $1934-1936=100$ \\
$1920-1939$ & 16.7 & 25.4 & \\
& 111.7 & 112.5 & 154.0 \\
$1955-1959$ & Post-1950: Indices with $1980=100$ & \\
$1980-1989$ & 22.9 & 26.7 & 116.7 \\
\hline
\end{tabular}

B.7. Expansion of manufacturing: Indices of industrial production, value added weights, $1980=100$ : sub-sectors other than machinery

\begin{tabular}{lrrrrrrrr}
\hline & & \multicolumn{3}{c}{ Heavy industry sub-sectors } & & \multicolumn{2}{c}{$\begin{array}{c}\text { Light industry } \\
\text { sub-sectors }\end{array}$} \\
\cline { 3 - 5 } \cline { 7 - 8 } Period & Total & $\begin{array}{c}\text { Iron } \\
\text { and steel }\end{array}$ & $\begin{array}{c}\text { Nonferrous } \\
\text { metals }\end{array}$ & Chemicals & & Textiles & $\begin{array}{c}\text { Food and } \\
\text { tobacco }\end{array}$ \\
\hline $1931-1935$ & 4.3 & 2.5 & 3.7 & 2.6 & & 26.2 & 18.9 \\
$1956-1960$ & 13.4 & 12.4 & 13.4 & 12.1 & & 36.5 & 31.6 \\
$1966-1970$ & 51.0 & 56.5 & 52.2 & 45.1 & & 83.1 & 70.9 \\
$1971-1975$ & 75.8 & 84.0 & 77.6 & 71.4 & & 100.5 & 86.1 \\
\hline
\end{tabular}

B.8. Expansion of production of machinery: Indices of industrial production, value added weights, $1980=100$ : Machinery sub-sector as a whole and for important sub-sectors of machinery production

\begin{tabular}{lccccc}
\hline Period & Total & $\begin{array}{c}\text { Nonelectric } \\
\text { machinery }\end{array}$ & $\begin{array}{c}\text { Electric } \\
\text { machinery }\end{array}$ & $\begin{array}{c}\text { Transport } \\
\text { equipment }\end{array}$ & $\begin{array}{c}\text { Precision } \\
\text { machinery }\end{array}$ \\
\hline $1931-1935$ & 0.8 & 2.1 & 0.2 & 0.6 & 0.8 \\
$1956-1960$ & 6.7 & 9.1 & 4.0 & 7.6 & 5.7 \\
$1966-1970$ & 37.5 & 29.1 & 29.1 & 42.9 & 22.0 \\
$1971-1975$ & 62.7 & 52.2 & 52.2 & 73.7 & 34.6 \\
\hline
\end{tabular}


Table A.9: $\quad$ (Continued)

C. Infrastructure and industry in China, 1895-2005

C.1. Expansion of traditional and modern freight transport, 1895-1936

\begin{tabular}{|c|c|c|c|c|c|}
\hline \multirow[b]{2}{*}{ Year } & \multicolumn{3}{|c|}{$\begin{array}{l}\text { Volumes (million tons-km) } \\
\text { transported by: }\end{array}$} & \multirow{2}{*}{$\begin{array}{c}\text { Share carried by } \\
\text { modern equipment } \\
\text { (steam ship and rail) }\end{array}$} & \multirow{2}{*}{$\begin{array}{c}\text { Index of total } \\
\text { volume }(1895=100)\end{array}$} \\
\hline & Rail & Steam ship & Junk & & \\
\hline 1895 & 0.2 & 5.2 & 24.1 & 16.8 & 100 \\
\hline 1915 & 7.3 & 16.3 & 35.8 & 36.2 & 189.8 \\
\hline 1933 & 12.8 & 25.9 & 51.2 & 41.2 & 291.3 \\
\hline 1936 & 14.6 & 26.6 & 54.3 & 41.4 & 309.0 \\
\hline
\end{tabular}

C.2. Expansion of railroad track and services and length of motor roads, 1895-1983: Indices with $1949=100$

\begin{tabular}{lcccc}
\hline & \multicolumn{3}{c}{ Railroads } & \\
\cline { 2 - 4 } Year & Track $(\mathbf{k m})$ & $\begin{array}{c}\text { Freight } \\
\text { (ton-km) }\end{array}$ & Passenger-km & $\begin{array}{c}\text { Length of } \\
\text { motor roads }\end{array}$ \\
\hline 1895 & 1.9 & 0.8 & 0.8 & n.e. \\
1915 & 48.2 & 31.8 & 25.7 & n.e. \\
1933 & 72.5 & 69.6 & 54.7 & 88.9 \\
1949 & 100.0 & 100.0 & 100.0 & 100.0 \\
1957 & 122.5 & 731.5 & 277.9 & 314.8 \\
1979 & n.e. & n.e. & n.e. & $1,081.5$ \\
1983 & 236.7 & $3,612.0$ & $2,380.8$ & n.e. \\
\hline
\end{tabular}

C.3. Output of chinese industry in 1933 prices (in billion Yuan)

\begin{tabular}{lccr}
\hline Sector & $\mathbf{1 9 3 3}$ & $\mathbf{1 9 5 2}$ & $\mathbf{1 9 5 7}$ \\
\hline Factories & 0.74 & 1.35 & 3.12 \\
Handicrafts & 2.22 & 2.33 & 2.66 \\
Mining & 0.23 & 0.68 & 1.40 \\
Utilities & 0.16 & 0.39 & 0.89 \\
Total & 3.35 & 4.75 & 8.07 \\
Share of handicrafts $(\%)$ & 66.3 & 49.05 & 32.96 \\
\hline
\end{tabular}


C.4. Growth rates for major sectors of GDP (\%) as estimated by Yeh and By Rawski ("preferred estimates" given by Rawski), 1914/1936

\begin{tabular}{lcc}
\hline Item & Yeh & Rawski \\
\hline Agriculture & 0.8 & $1.4-1.7$ \\
Modern industry & 7.7 & 8.1 \\
Handicrafts & 0.7 & 1.4 \\
Construction & 3.5 & 4.6 \\
Modern transportation/ & 4.0 & 3.0 \\
communications & & \\
Traditional transportation/ & 0.3 & 1.9 \\
communications & & \\
Trade & 1.1 & 2.5 \\
Finance & 2.9 & 5.0 \\
GDP & 1.1 & $1.8-2.0$
\end{tabular}

C.5. Share of regions in china's manufacturing output in 1933 and percentage of firms in each region that are Chinese

\begin{tabular}{lcc}
\hline Region & Share of region (\%) & Share of Chinese firms (\%) \\
\hline China Proper (excluding & & \\
manchuria) & 85.8 & 78.1 \\
Shanghai & 39.7 & 69.2 \\
Kiangsu & 8.7 & 97.8 \\
Other & 37.3 & 82.9 \\
Manchuria & 14.2 & 41.1 \\
\hline
\end{tabular}

C.6. Cost (Yuan) for a bale of 20-count yarn in Chinese and Japanese mills in China, $1930 \mathrm{~s}$

\begin{tabular}{lcccc}
\hline Item & $\begin{array}{c}\text { Chinese } \\
\text { mills (1) }\end{array}$ & $\begin{array}{c}\text { Japanese } \\
\text { mills (2) }\end{array}$ & $\begin{array}{c}\text { Difference } \\
(\mathbf{1})-(\mathbf{2})\end{array}$ & $\begin{array}{c}\text { Contribution } \\
\text { to total } \\
\text { difference (\%) }\end{array}$ \\
\hline Wages & 10.5 & 5.8 & 4.7 & 20.2 \\
Power & 5.5 & 4.8 & 0.7 & 3.0 \\
Machine repairs & 1.8 & 0.6 & 1.2 & 5.2 \\
Materials & 1.7 & 0.5 & 1.2 & 5.2 \\
Salaries & 1.2 & 0.6 & 0.6 & 2.6 \\
Sanitation & 0.2 & 0.5 & -0.3 & -1.3 \\
Management & 2.5 & 2.0 & 0.5 & 2.2 \\
Taxes and interest & 15.0 & 2.7 & 12.3 & 52.8 \\
Total & 43.7 & 20.4 & 23.3 & 100.0 \\
\hline
\end{tabular}


Table A.9: (Continued)

C.7. Growth rates for employment in light and heavy industry, 1952-1999

\begin{tabular}{lcc}
\hline Period & Light $\mathbf{( \% )}$ & Heavy $(\boldsymbol{\%})$ \\
\hline $1952-1978$ & 8.7 & 11.9 \\
$1978-1989$ & 15.4 & 12.9 \\
$1989-1999$ & 15.1 & 16.6 \\
\hline
\end{tabular}

C.8. Relative labor productivity (Yuan per worker) of labor in commune and village enterprises, 1978-1983

\begin{tabular}{lcccc}
\hline & $\begin{array}{c}\text { Percentage of } \\
\text { employment } \\
\text { in industry } \\
\mathbf{( 1 )}\end{array}$ & $\begin{array}{c}\text { Labor } \\
\text { productivity in } \\
\text { agriculture } \\
\mathbf{( 2 )}\end{array}$ & $\begin{array}{c}\text { Labor } \\
\text { productivity } \\
\text { in industry (3) }\end{array}$ & $\begin{array}{c}\text { Ratio (\%) } \\
\mathbf{( 2 ) / ( 3 )}\end{array}$ \\
\hline $1978-1989$ & 75.8 & 658.5 & 2278.5 & 28.9 \\
$1980-1981$ & 82.5 & 845.0 & 2773.5 & 34.0 \\
$1982-1983$ & 86.7 & 1290.0 & 3304.0 & 39.0 \\
\hline
\end{tabular}

C.9 Indices for employment in textiles and apparel (INDEM), $1980=100$, employment per firm (SIZE), share of sector in total exports (EXPS), and share of china's textiles exports in world exports (WEXPS), 1980-2005

\begin{tabular}{lcccc}
\hline Year & INDEM & SIZE & EXPS (\%) & WEXPS (\%) \\
\hline 1980 & 100.0 & 132.5 & 19.8 & 4.6 \\
1990 & 247.6 & 148.3 & 20.1 & 7.5 \\
2000 & 161.6 & 387.6 & 19.8 & 14.7 \\
2005 & 194.8 & 271.8 & 15.4 & 24.1 \\
\hline
\end{tabular}

C.10. Indices for output (INDO), employment (INDEM) and output per man year (INDLP) and ratio of the difference between exports and imports relative to output (EX-IM/O), steel industry, 1980-2005

\begin{tabular}{lcccc}
\hline Year & INDO & INDEM & INDLP & EX-IM/O (\%) \\
\hline 1980 & 100.0 & 100.0 & 100.0 & -12.1 \\
1990 & 179.0 & 129.1 & 138.8 & -2.4 \\
2000 & 346.4 & 103.3 & 335.5 & -7.9 \\
2005 & 952.0 & 115.2 & 827.0 & -1.5 \\
\hline
\end{tabular}


Table A.9: $\quad$ (Continued)

C.11. Share of Chinese bank loans by type

\begin{tabular}{|c|c|c|c|c|c|c|}
\hline Period & $\begin{array}{c}\text { Industrial } \\
(\%)\end{array}$ & $\begin{array}{l}\text { Infrastruc- } \\
\text { ture }(\%)\end{array}$ & $\begin{array}{l}\text { Agricul- } \\
\text { tural (\%) }\end{array}$ & $\begin{array}{c}\text { Town and } \\
\text { village en- } \\
\text { terprises } \\
(\%)\end{array}$ & $\begin{array}{c}\text { Privately } \\
\text { owned } \\
\text { firms } \\
(\%)\end{array}$ & $\begin{array}{c}\text { Joint } \\
\text { ventures } \\
(\%)\end{array}$ \\
\hline $\begin{array}{l}1995- \\
1999\end{array}$ & 21.7 & 1.8 & 4.2 & 5.9 & 0.5 & 2.6 \\
\hline $\begin{array}{l}2000- \\
2005\end{array}$ & 15.4 & 1.8 & 5.2 & 5.3 & 0.9 & 2.2 \\
\hline
\end{tabular}

${ }^{a}$ In the case of Japan circa 2000 the figures for railway track are for 1984. The figures for Japan's road length and electricity generated are for 1921, not 1920. Figures on paved road length are not available for Japan until 1936. In order to estimate China's paved road length for 2000 I relied on an estimate of 11 vehicles per $\mathrm{km}$ of roads, multiplying by the number 11 the number of reported vehicles.

${ }^{\mathrm{b}}$ In the case of traditional transport the indices for 1930-1941 are actually for 1930-1938.

${ }^{\mathrm{c}}$ In the case of electricity supplied, the figures for 1910-1919 are actually for 1915-1919.

n.e.: not estimated.

Sources: For Panel A the sources for Japan are various tables in Japan Ministry of Internal Affairs and Communications and Statistical Research and Training Institute (2009); for China the sources are various tables in the following: China National Bureau of Statistics (2004), Maddison (1998, 2006), Mitchell (2003), Rawski (1989), United Nations (2004), and World Bank (2002). For Panels B.1-B.4 various tables in Mosk (2001). For Panels B.5 and B.6 various tables in Mosk (2005). For Panels B.7 and B.8 p. 251 of Mosk (2008). For Panels C.1, C.2, C.4, C.5, and C.6 various tables in Rawski (1989). For Panel C.3 p. 146 in Maddison (1998). For Panels C.7 and C.8 various tables in Bramall (2009). For Panels C.9 and C.10 various tables in Brandt et al. (2008). For Panel C.11 p. 521 in Allen et al. (2008).

collective farming system for the diversity of agricultural output: under the regime of family farming and relatively unconstrained market conditions, relative prices largely determining production decisions, greater flexibility in responding to demand taking hold.

Table A.9 documents assertions made about infrastructure and industry. Panel A substantiates one of my key assertions: that infrastructure expansion was far more advanced in the Japan of 1920 than it was in the China of 1920. This is clear, Japan's superiority showing up both in terms of population and in terms of geography. Panel B.1 speaks to the importance of railroads in modernizing transport in pre-1941 Japan. Noteworthy is the sharp drop in traditional means of transport (using human pulled rikusha on the land and small boats, kobune, on the water). Panels B.2-B.4 document the 
crucial importance of electrification for the modernization of railroads and mechanization in factories in pre-1940 Japan. Panels B.5 and B.6 testify to the dramatic expansion of transport and communications in post1955 Japan, the relative price of transport declining between the late 1950s and the late 1980s (a similar tendency is at work in the period between the late 1980s and two decades prior to 1940). Panel B.7 documents the massive expansion of heavy industry (chemicals, iron and steel) that took place in Japan after 1955, growth in the heavy industries outstripping growth in textiles and food and tobacco. Panel B.8 demonstrates the importance of machinery production for the surge in Japanese manufacturing in the post-1955 period.

Panels C.1-C.11 of Table A.9 offer parallel figures for China. Panel C.1 shows that traditional transport declined much more slowly in pre-1940 China than it did in pre-1940 Japan. Panel C.3 suggests that handicrafts as opposed to factory production remained strongly entrenched in China, dominating industrial output during the 1930 s, continuing to play a substantial role as late as 1957. Panel C.4 provides two sets of estimates for national output growth in China between 1914 and 1936 the more cautious figures of Yeh contrasted with the more optimistic estimates arrived at by Rawski. It is important to note that the main difference between the two estimates lies in the estimates for the agricultural sector, not the industrial sector. Panel C.5 speaks to the strong regional concentration of China's manufacturing during the pre-1940 period, Shanghai and Manchuria dominating. Panel C.6 decomposes the advantage enjoyed by Japanese managed mills operating in China over their Chinese mill rivals: the main differences being wages and taxes plus interest paid. Panels C.7-C.11 explores the massive expansion of industry in post1952 China. Panel C.7 contrasts the period 1952-1978 when heavy industrial growth outstripped light industry growth with the period after reforms were introduced, light industry growing more briskly than heavy industry between 1978 and 1987. Along these lines, Panel C.9 shows the crucial importance of textiles in the surge of China's exports after 1980, especially prior to 2000 (mimicking the importance of textiles in Japan's exports prior to the early 1960s). Finally Panel C.11 indicates that private Chinese firms have been largely shut out of the loan profiles of official Chinese banks.

The final table in this Appendix, Table A.10, presents growth accounting estimates for both Japan and China — and for Hong Kong, South Korea, and Taiwan - going back to 1888 in the case of Japan. Key points to be culled from this table include: (1) the pace of total factor productivity growth 
accelerated in Japan, peaking in the 1958-1970 period, declining thereafter; (2) during the period 1953-1971 when total factor productivity growth was unusually rapid in Japan economies of scale and structural change played a crucial role in the expansion of total factor productivity; (3) within the Japanese manufacturing economy some sectors - notably machinery and trade - experienced relatively high rates of total factor productivity growth while other sectors like water supply, agriculture, and medical services experienced low even negative total factor productivity growth (when total factor productivity growth is negative augmentation of land, labor, and capital outstrip the negative impact of total factor productivity growth, resources gaining in inherent efficiency being thrown into sectors that are not finding more efficient ways to utilize them); (4) total factor productivity growth was also rapid in Hong Kong, South Korea, and Taiwan over much of the

Table A.10: Growth accounting for Japan, Hong Kong, South Korea, Taiwan, and China, mainly post-1950.

A. Japan

A.1. Long-run estimates, 1888-1990 for the growth in labor productivity

\begin{tabular}{|c|c|c|c|c|c|}
\hline Period & $\begin{array}{c}{[1]} \\
\text { Capital- } \\
\text { income } \\
\text { share }\end{array}$ & $\begin{array}{c}{[2]} \\
\text { Labor } \\
\text { productivity }\end{array}$ & $\begin{array}{c}{[3]} \\
\text { Capital- } \\
\text { labor ratio }\end{array}$ & $\begin{array}{l}\text { [4] Total fac- } \\
\text { tor produc- } \\
\text { tivity (TFP) } \\
\text { growth }\end{array}$ & $\begin{array}{c}\text { [5] Contri- } \\
\text { bution of } \\
\text { TFP growth } \\
{[4] /[2](\%)}\end{array}$ \\
\hline \multicolumn{6}{|c|}{ A.1.1. Pre-World War II } \\
\hline $\begin{array}{l}1888- \\
1900\end{array}$ & 0.33 & 2.08 & 5.74 & 0.19 & 9 \\
\hline $\begin{array}{l}1900- \\
1920\end{array}$ & 0.39 & 2.68 & 6.07 & 0.31 & 12 \\
\hline $\begin{array}{l}1920- \\
1937\end{array}$ & 0.43 & 2.29 & 2.75 & 1.11 & 48 \\
\hline $\begin{array}{l}1928- \\
1937\end{array}$ & 0.47 & 3.04 & 2.23 & 1.99 & 65 \\
\hline \multicolumn{6}{|c|}{ A.1.2. Post-World War II } \\
\hline $\begin{array}{l}1958- \\
1970\end{array}$ & 0.33 & 8.19 & 11.60 & 4.36 & 53 \\
\hline $\begin{array}{l}1970- \\
1990\end{array}$ & 0.28 & 3.78 & 7.44 & 1.70 & 45 \\
\hline
\end{tabular}




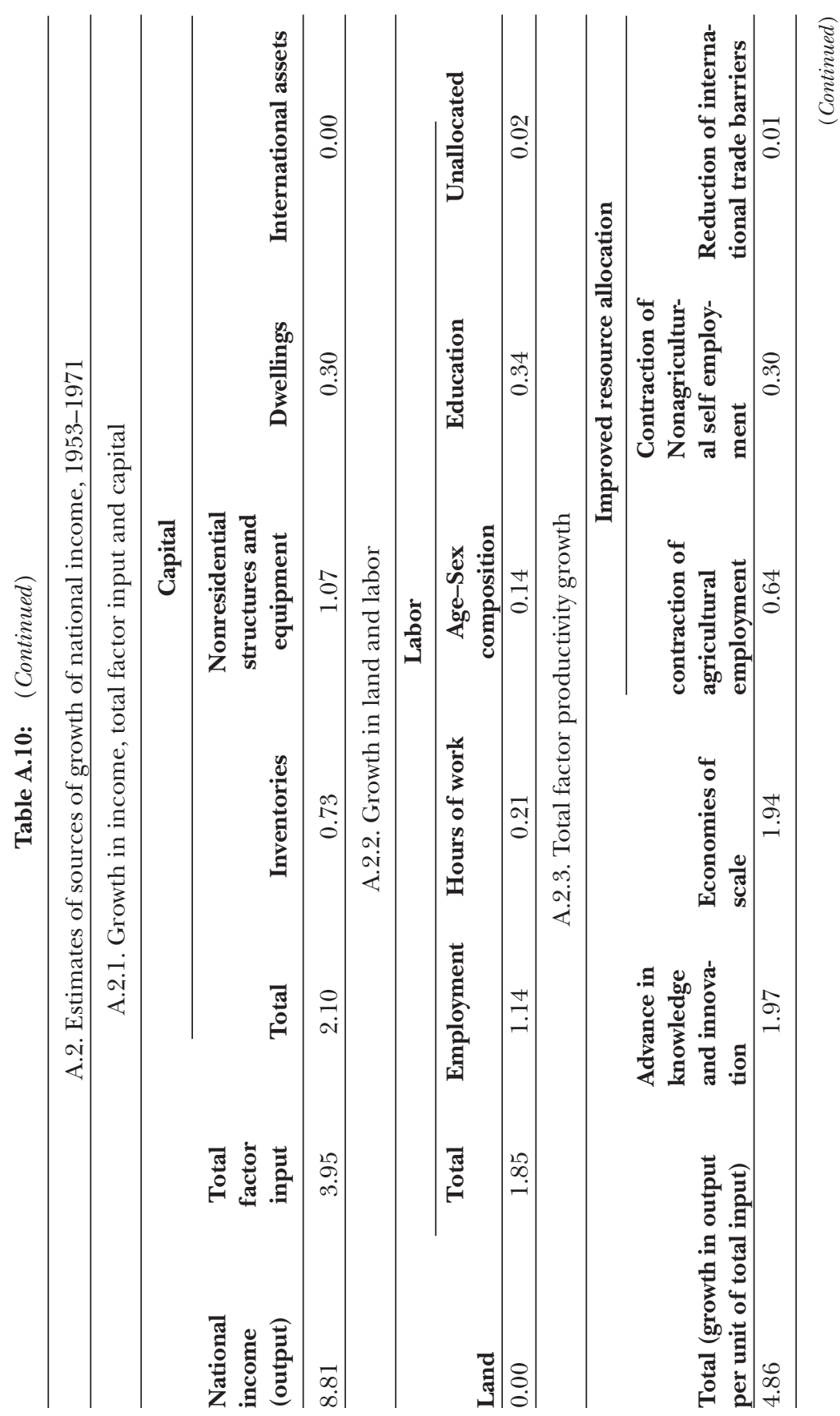


Table A.10: (Continued)

A.3. Sector specific estimates of total factor productivity growth, 1961-1995

Top ten (over 1961-1995 period) (\%) Bottom ten (over 1961-1995 period) (\%)

\begin{tabular}{|c|c|c|c|c|c|}
\hline Sector & $\begin{array}{c}1961- \\
1973\end{array}$ & $\begin{array}{c}1961- \\
1995\end{array}$ & Sector & $\begin{array}{c}1961- \\
1973\end{array}$ & $\begin{array}{c}1961- \\
1995\end{array}$ \\
\hline Air transportation & 6.95 & 3.11 & Water supply & -3.92 & -2.12 \\
\hline Electric machinery & 4.18 & 2.93 & Other industries & -2.85 & -2.05 \\
\hline Gas & 2.86 & 2.36 & Publishing & -2.32 & -1.49 \\
\hline Trade & 4.54 & 2.32 & Agriculture & -2.24 & -1.43 \\
\hline Precision machinery & 3.39 & 2.19 & Education & 2.32 & -0.63 \\
\hline Communications & 1.79 & 2.01 & $\begin{array}{l}\text { Railway } \\
\text { transportation }\end{array}$ & 0.67 & -0.59 \\
\hline $\begin{array}{l}\text { Other mining (not } \\
\text { coal) }\end{array}$ & 5.45 & 1.73 & Coal & -0.63 & -0.52 \\
\hline Chemicals & 2.91 & 1.65 & $\begin{array}{l}\text { Building and } \\
\text { construction }\end{array}$ & -0.94 & -0.34 \\
\hline Vehicles & 2.47 & 1.53 & Foods & -0.08 & -0.29 \\
\hline Public services & 3.91 & 1.46 & Medical services & 0.25 & -0.22 \\
\hline
\end{tabular}

B. Estimates for the growth in total factor productivity: Hong Kong, South Korea, and Taiwan, 1960-1999

\begin{tabular}{|c|c|c|c|c|c|}
\hline Period & $\begin{array}{c}{[1]} \\
\text { Capital- } \\
\text { income } \\
\text { share }\end{array}$ & $\begin{array}{c}{[2]} \\
\text { Labor pro- } \\
\text { ductivity }\end{array}$ & $\begin{array}{c}{[3]} \\
\text { Capital- } \\
\text { labor } \\
\text { ratio }\end{array}$ & $\begin{array}{l}{[4]} \\
\text { Total factor } \\
\text { productiv- } \\
\text { ity (TFP) } \\
\text { growth }\end{array}$ & $\begin{array}{c}{[5]} \\
\text { Contri- } \\
\text { bution } \\
\text { of TFP } \\
\text { growth } \\
{[4] /[2]} \\
(\%)\end{array}$ \\
\hline \multicolumn{6}{|c|}{ B.1.Hong Kong } \\
\hline 1966-1970 & 0.34 & 4.1 & 5.9 & 2.1 & 51 \\
\hline 1970-1980 & 0.358 & 6.0 & 5.4 & 4.0 & 67 \\
\hline 1980-1990 & 0.399 & 5.7 & 6.5 & 3.2 & 55 \\
\hline 1990-1999 & 0.391 & 1.9 & 6.5 & -0.7 & -36 \\
\hline \multicolumn{6}{|c|}{ B.2. South Korea } \\
\hline 1970-1980 & 0.478 & 3.6 & 9.6 & -1.0 & -27 \\
\hline 1980-1990 & 0.429 & 6.2 & 8.7 & 2.5 & 40 \\
\hline 1990-1999 & 0.389 & 4.4 & 8.6 & 1.1 & 25 \\
\hline
\end{tabular}


Table A.10: (Continued)

\begin{tabular}{lrlrrr}
\hline \multicolumn{5}{c}{ B.3. Taiwan } \\
$1960-1970$ & 0.485 & 7.0 & 10.9 & 1.7 & 24 \\
$1970-1980$ & 0.476 & 5.4 & 10.7 & 0.3 & 2 \\
$1980-1990$ & 0.435 & 6.2 & 6.7 & 3.2 & 52 \\
$1990-1999$ & 0.417 & 6.3 & 8.6 & 2.7 & 43 \\
\hline
\end{tabular}

\section{China}

C.1. Growth accounting estimates for china, 1952-2005 contributions to growth of national domestic product (GDP)

\begin{tabular}{lccccc}
\hline \multicolumn{5}{c}{ C.1.1. Growth of output and inputs } \\
\hline & & \multicolumn{5}{c}{ Average growth of inputs } \\
\cline { 3 - 6 } & & \multicolumn{5}{c}{$\begin{array}{c}\text { Education- } \\
\text { enhanced } \\
\text { Period }\end{array}$} & $\begin{array}{c}\text { Growth in } \\
\text { GDP }\end{array}$ & Capital & $\begin{array}{c}\text { Total factor } \\
\text { productivity } \\
\text { growth (TFP) }\end{array}$ \\
\hline $1952-2005$ & 7.0 & 7.7 & 1.9 & 2.6 & 2.1 \\
& & & $1952-1978$ & & \\
$1952-1978$ & 4.4 & 5.8 & 1.9 & 2.5 & 0.5 \\
$1952-1957$ & 6.5 & 1.9 & 1.2 & 1.7 & 4.7 \\
$1957-1978$ & 3.9 & 6.7 & 2.0 & 2.7 & -0.5 \\
$1957-1965$ & 2.4 & 5.2 & 1.5 & 2.1 & -1.0 \\
$1965-1978$ & 4.9 & 7.7 & 2.4 & 3.1 & -0.2 \\
& & & $1978-2005$ & & 3.8 \\
$1978-2005$ & 9.5 & 9.6 & 1.9 & 2.7 & 3.2 \\
$1978-1985$ & 9.7 & 9.2 & 3.4 & 4.5 & 3.1 \\
$1985-1990$ & 7.7 & 6.9 & 2.5 & 2.9 & 6.7 \\
$1990-1995$ & 11.7 & 9.1 & 1.4 & 1.9 & 3.2 \\
$1995-2000$ & 8.6 & 10.5 & 0.9 & 1.6 & 3.1 \\
$2000-2005$ & 9.5 & 12.6 & 1.0 & 1.8 &
\end{tabular}

C.1.2. Percentage shares of GDP growth attributable to

\begin{tabular}{cccc}
\hline & $\begin{array}{c}\text { Capital } \\
\mathbf{( \% )}\end{array}$ & $\begin{array}{c}\text { Education-enhanced } \\
\text { labor }(\boldsymbol{\%})\end{array}$ & $\begin{array}{c}\text { Total factor productivity } \\
\text { growth (TFP) } \mathbf{( \% )}\end{array}$ \\
\hline $1952-2005$ & 47.7 & 21.4 & 30.9 \\
$1952-1978$ & 56.3 & 32.7 & 11.0 \\
$1978-2005$ & 43.7 & 16.2 & 40.1 \\
\hline
\end{tabular}


Table A.10: (Continued)

C.2. Various estimates of total factor productivity growth, 1980s and 1990s, range a

\begin{tabular}{lcc}
\hline Data used & $\mathbf{1 9 8 0} \mathrm{s}$ & $\mathbf{1 9 9 0 \mathbf { s }}$ \\
\hline National level GDP data & $2.1-3.7$ (4 estimates) & $0.3-2.8$ (4 estimates) \\
Provincial level GDP data & $0.4-5.5$ (4 estimates) & $1.8-6.3$ (3 estimates) \\
Industry level data & $3.1-6.5$ (2 estimates) & $0.5-3.8$ (2 estimates) \\
\hline
\end{tabular}

C.3. Estimates of total factor productivity growth in independent-accounting industrial enterprises, $1980-1996^{\mathrm{b}}$

\begin{tabular}{lcccc}
\hline Period & $\begin{array}{c}\text { State owned } \\
\text { enterprises }\end{array}$ & $\begin{array}{c}\text { Collectively } \\
\text { owned } \\
\text { enterprises }\end{array}$ & $\begin{array}{c}\text { Other domestic } \\
\text { enterprises }\end{array}$ & $\begin{array}{c}\text { Foreign invested } \\
\text { companies }\end{array}$ \\
\hline $1980-1984$ & 2.1 & 3.1 & n.a. & n.a. \\
$1984-1988$ & 3.8 & 5.2 & n.a. & n.a. \\
$1988-1992$ & 2.1 & 3.1 & 2.1 & 1.1 \\
$1992-1996$ & -1.1 & 4.3 & 3.1 & 0.7 \\
$1980-1996$ & 1.7 & 3.9 & n.a. & n.a. \\
\hline
\end{tabular}

${ }^{a}$ Some of the estimates for the 1980s cover the period from the late 1970s until the early 1990s. For the 1990s estimates for the second half of the decade tend to be lower than those for the first half of the decade.

${ }^{\mathrm{b}}$ n.a. $=$ not available.

Sources: For Panel A.1 p. 34 of Kim (2001). For Panel A.2 p. 98-99 of Denison and Chung (1976). For Panel A.3 pp. 173-174 of Nakajima et al. (2004). For Panel B p.36 of Kim (2001). For Panel C.1, p.839 of Perkins and Rawski (2008). For Panel C.2 p.416 of Bramall (2009). For Panel C.3 p.540 of Huang (2008).

post-1960 period, like Japan slowing down in the case of Hong Kong and Taiwan (giving manufacturers in these two jurisdictions a strong incentive to invest in China where labor costs were lower, wages rising with already achieved labor productivity gains in Hong Kong and Taiwan); and (5) total factor productivity growth was relatively slow in China during the heyday of the command and control economy, 1952-1978, picking up in the period after agricultural reforms and subsequent reforms associated with opening China up to foreign investment in manufacturing were introduced.

We can summarize these ideas concerning the pace of total factor productivity growth with the concept of an "arc of total factor productivity growth." When a country is absorbing and adapting a huge range 
of technologies from abroad the rate of total factor productivity growth is generally high. Moreover, as argued earlier, rapid absorption of foreign technology is typically associated with augmentation and physical capital accumulation. So during this phase total factor productivity growth tends to drift upward especially in newly established industries where the pace of technological adaptation is unusually rapid (e.g., in air transport, electrical machinery, and precision machinery in Japan between 1961 and 1973). At the same time in older more established industries total factor productivity growth may actually be negative during this phase (e.g., in agriculture, coal, and building construction) because the rate of growth in the augmentation of the factors of production actually outstrips the rate of growth of output. The aggregate level of total factor productivity growth is an amalgam of the individual sector total factor productivity growths (weighted through by the shares of the sectors in overall output). This is the dynamic during an upswing phase in the arc.

Eventually a follower country either catches up or at least closes the gap with the technological leaders in industry after industry, thereby dampening the rate of total factor productivity in all sectors. The pace of overall total factor productivity growth slackens overall as the downswing phase of the arc gains force.

During the long downswing phase - basically the fate of all economies once they make great strides in closing the technological gap with the leading economies - there is a strong incentive to seek opportunities for investment in other countries with lower wages (ones that do not enjoy the standard of living and hence the high wages associated with the more sophisticated technology and augmented labor of the home country). To some extent this is what happened in East Asia. A combination of absorbing foreign technology, accumulation, and augmentation of the factors of production drove up wages and eventually reduced the pace of total factor productivity growth - hence the rate of growth of per capita income in Japan, South Korea, Taiwan, and Hong Kong by the late 1970s (see Table A.5). Naturally owners of capital, investors, in these countries began to look around for investment opportunities in their geographic neighborhood, namely in China where the market was huge and wages were far lower. At the same time Chinese leaders, realizing that the types of income per capita gaps evident for East Asia during the 1970s could not be perpetuated ad infinitum without inviting domestic political unrest realized the handwriting was on the wall. Some accommodation with the demands of foreign capitalists for relatively safe (that is not subject to Chinese nationalization) 
investment opportunities within China was called for. As a result Special Economic Zones were established along the Chinese coastline.

\section{Endnotes}

1. For details on national income accounting and a more extensive discussion concerning the practical difficulties encountered in estimating income see Mosk (2008: pp. 20-23 and pp. 353-367).

2. For Maddison's defense of his use of 1990 international Geary-Khamis dollars to compute levels of income per capita comparable across different time periods and different countries see Maddison (1998, 2006, 2007). Maddison's estimates appear in (or underlie figures appearing in) Tables A.2-A.6, and A.9 in this Appendix. While Maddison's assumptions and methodology in generating his estimates has been criticized, his figures are widely used in the economic development literature. This author believes that they are the most reliable currently available.

3. My approach differs from that employed by Bramall (2009). Bramall (2009) uses life expectancy as the principal gauge of the standard of living, improvements in life expectancy as the main calibrator of economic development gains. 


\section{Bibliography}

Allen, F.; Qian, J. and Qian, M. (2008) "China's Financial System: Past, Present, and Future," in L. Brandt and T. G. Rawski (eds.) China's Great Economic Transformation (New York: Cambridge University Press).

Bell, L. (1992) "Farming, Sericulture, and Peasant Rationality in Wuxi County in the Early Twentieth Century," in T. Rawski and L. Li (eds.) Chinese History in Economic Perspective (Berkeley and Los Angeles: University of California Press).

Bell, L. (1999) One Industry, Two Chinas: Silk Filatures and Peasant-Family Production in Wuxi County, 1865-1937 (Stanford: Stanford University Press).

Bian, M. (2005) The Making of the State Enterprise System in Modern China (Cambridge, MA: Harvard University Press).

Blackmore, S. (2001) "Evolution: The Human Brain as a Selective Imitation Device," Cybernetics and Systems, 32(1): 225-255.

Bo, Z. (2007) China's Elite Politics: Political Transition and Power Balancing (Singapore: World Scientific).

Bramall, C. (2009) Chinese Economic Development (New York: Routledge).

Brandt, L.; Hsieh, C. and Zhu, X. (2008) "Growth and Structural Transformation in China," in L. Brandt and T. G. Rawski (eds.) China's Great Economic Transformation (New York: Cambridge University Press).

Brandt, L.; Rawski, T.G. and Sutton, J. (2008) "China's Industrial Development," in L. Brandt and T. G. Rawski (eds.) China's Great Economic Transformation (New York: Cambridge University Press). 
Brandt, L. and Sands, B. (1992) "Land Concentration and Income Distribution in Republican China,” in T. Rawski and L. Li (eds.) Chinese History in Economic Perspective (Berkeley and Los Angeles: University of California Press).

Cai, F.; Park, A. and Zhao, Y. (2008) "The Chinese Labor Market in the Reform Era," in L. Brandt and T. G. Rawski (eds.) China's Great Economic Transformation (New York: Cambridge University Press).

Campbell, C. and Lee, J. (2004) "Mortality and Household in Seven Liaodong Populations, 1749-1909," in T. Bengtsson, C. Campbell, J. Lee, et al. (eds.) Life Under Pressure: Mortality and Living Standards in Europe and Asia, 1700-1900 (Cambridge, MA: MIT Press).

Campbell, C. and Lee, J. (2005) "Deliberate Fertility in Late Imperial China: Spacing and Stopping in the Qing Imperial Lineage," California Center for Population Research On-Line Working Paper Series CCPR-041-05.

Chang, C. (1962) The Income of the Chinese Gentry (Seattle: University of Washington Press).

Chao, K. (1975) "The Growth of a Modern Textile Industry and the Competition with Handicrafts," in D. Perkins (ed.) China's Modern Economy in Historical Perspective (Stanford: Stanford University Press).

Chao, K. (1982) The Economic Development of Manchuria: The Rise of a Frontier Economy (Ann Arbor: Center for Chinese Studies).

Chen, X. (1991) "Chin's City Hierarchy, Urban Policy and Spatial Development in the 1980s," Urban Studies, 28(3): 341-367.

Chen, Y. (1983) Chen Yun's Strategy for China's Development: A Non-Maoist Alternative (Armonk, N.Y.: M. E. Sharpe, edited by N. Lardy and K. Lieberthal, translated by T. Mao and A. Du).

Cheng, L. (2003) Banking in Modern China: Entrepreneurs, Professional Managers, and the Development of Chinese Banks, 1897-1937 (New York: Cambridge University Press).

China National Bureau of Statistics (2004) China Statistical Yearbook 2004 (Beijing: China Statistics Press).

Ch'ü, T. (1962) Local Government in China Under the Ch'ing (Cambridge, MA: Harvard University Press).

Clark, G. (2007) A Farewell to Alms: A Brief Economic History of the World (Princeton: Princeton University Press).

Collier, P. (2007) The Bottom Billion: Why the Poorest Countries are Failing and What Can Be Done About It (New York: Oxford University Press).

Dawkins, R. (2006) The Selfish Gene (New York: Oxford University Press, reprint of original 1976 edition).

Denison, E. and Chung, W. (1976) "Economic Growth and Its Sources," in H. Patrick and H. Rosovsky (eds.) Asia's New Giant: How the Japanese Economy Works (Washington, D.C.: The Brookings Institution). 
Diamond, J. (1999) Guns, Germs, and Steel: The Fates of Human Societies (New York: W.W. Norton \& Company).

Duus, P. (1989a) “Japan's Informal Empire in China, 1895-1937,” in P. Duus, R. Myers, and M. Peattie (eds.) The Japanese Informal Empire in China, 18951937 (Princeton: Princeton University Press).

Duus, P. (1989b) “Zaikabō: Japanese Cotton Mills in China, 1895-1937," in P. Duus, R. Myers, and M. Peattie (eds.) The Japanese Informal Empire in China, 1989 1937 (Princeton: Princeton University Press).

Easterly, W. (2002) TheElusive Quest for Growth:Economists'Adventures and Misadventures in the Tropics (Cambridge, MA: The MIT Press).

Elliot, M. (2001) The Manchu Way: The Eight Banners and Ethnic Identity in Late Imperial China (Stanford: Stanford University Press).

Elman, B. (2000) A Cultural History of Civil Examinations in Imperial China (Berkeley: University of California Press)

Elman, B. (2006) A Cultural History of Modern Science in China (Cambridge, MA: Harvard University Press).

Engelen, T. (2006) "Low Fertility in Premodern China: Positive, Preventive or Proactive Behavior?," History of the Family, 11 (3): 125-134.

Fairbank, J. K. (1986) The Great Chinese Revolution: 1800-1985 (New York: Harper \& Row).

Faure, D. (1989) The Rural Economy of Pre-Liberation China: Trade Expansion and Peasant Livelihood in Jiangsu and Gunagdong, 1870 to 1937 (New York: Oxford University Press).

Feuerwerker, A. (1977) Economic Trends in the Republic of China, 1912-1949 (Ann Arbor: The University of Michigan).

Giersch, C. (2006) Asian Borderlands: The Transformation of Qing China's Yunnan Frontier (Cambridge, MA: Harvard University Press).

Hall, A. (1966) The Scientific Revolution 1500-1800: The Formation of the Modern Scientific Attitude (Boston: Beacon Press, reprint of original 1962 second edition).

Hannum, E.; Behrman, J.; Wang, M. and Liu, J. (2008) "Education in the Reform Era," in L. Brandt and T. G. Rawski (eds.) China's Great Economic Transformation (New York: Cambridge University Press).

Hirschmeier, J. (1964) The Origins of Entrepreneurship in Meiji Japan (Cambridge, MA: Harvard University Press).

Ho, P. (1959) Studies on the Population of China, 1368-1953 (Cambridge, MA: Harvard University Press).

Hoffman, P. (2005) "Why Is It That Europeans Ended Up Conquering the Rest of the Globe? Prices, the Military Revolution, and Western Europe's Comparative Advantage in Violence" (unpublished manuscript).

Houston, R. (1988) Literacy in Early Modern Europe: Culture and Education, 1500-1800 (New York: Longman). 
Huang, C. (1990) The Peasant Family and Rural Development in the Yangzi Delta, 13501988 (Stanford: Stanford University Press).

Huang, J.; Otsuka, K. and Rozelle, S. (2008) “Agriculture in China's Development: Past Disappointments, Recent Successes, and Future Challenges," in L. Brandt and T. G. Rawski (eds.) China's Great Economic Transformation (New York: Cambridge University Press).

Huang, P. (1985) The Peasant Economy and Social Change in North China (Stanford: Stanford University Press).

Huang, Y. (2008) "China” in A. K. Dutt and J. Ros (eds.), International Handbook of Development Economics. Volume Two (Northampton, MA: Edward Elgar).

Hunter, J. (2003) Women and the Labour Market in Japan's Industrializing Economy: The Textile Industry Before the Pacific War (New York: Routledge).

Jansen, M. (1975) Japan and China: from War to Peace, 1894-1972 (Chicago: Rand McNally College Publishing Company).

Japan Ministry of Internal Affairs and Communications and Statistical Research and Training Institute (2009), "Historical Statistics for Japan" available at www.stat. go.jp/english/chouki (downloaded in February 2009).

Jones, S. (1972) “Finance in Ningpo: The 'Ch'ien Chuang,' 1750-1880," in W. Willmott (ed) Economic Organization in Chinese Society (Stanford: Stanford University Press).

Jordan, D. (1991) Chinese Boycotts versus Japanese Bombs: The Failure of China's "Revolutionary Diplomacy," 1931-32 (Ann Arbor: The University of Michigan Press).

Junji, B. (1989) "Japanese Industrialists and Merchants in the Anti-Japanese Boycotts in China, 1919-1928," in P. Duus, R. Myers and M. Peattie (eds.) The Japanese Informal Empire in China, 1989-1937 (Princeton: Princeton University Press).

Kim, J. (2001) "Total Factor Productivity Growth in East Asia: Implications for Future Growth" available online, downloaded in January 2009.

Klemm, F. (1964) A History of Western Technology (Cambridge, MA: The MIT Press).

Kueh, Y. (1995) Agricultural Instability in China, 1931-1991: Weather, Technology, and Institutions (New York: Oxford University Press).

Kuhn, T. (1962) The Structure of Scientific Revolutions (Chicago: University of Chicago Press).

Landes, D. (1998) The Wealth and Poverty of Nations: Why Some Are So Rich and Some So Poor (New York: W.W. Norton and Company).

Lee, J. and Campbell, C. (1997) Fate and Fortune in Rural China: Social Organization and Population Behavior in Liaoning, 1774-1873 (New York: Cambridge University Press).

Lee, J. and Tan, G. (1992) "Infanticide and Family Planning in Late Imperial China: The Price and Population History of Rural Liaoning, 1774-1873," 
in T. Rawski and L. Li (eds.) Chinese History in Economic Perspective (Berkeley and Los Angeles: University of California Press).

Lewis, A. (1954) "Economic Development with Unlimited Supplies of Labor," The Manchester School, 22: 141-145.

Lewis, A. (1978) The Evolution of the International Economic Order (Princeton: Princeton University Press).

Li, L. (1981) China's Silk Trade: Traditional Industry in the Modern World, 1842-1937 (Cambridge, MA: Harvard University Press).

Li, Y. (2001) Chinese Bureaucratic Culture and Its Influence on the 19th-Century Steamship Operation, 1864-1885: The Bureau of Recruiting Merchants (New York: The EdwinMellen Press).

Lin, A. (1997) The Rural Economy of Guangdong, 1870-1937: A Study of the Agrarian Crisis and Its Origins in Southernmost China (Houndmills, Basingstoke, Hampshire: Macmillan Press Ltd).

Liu, C. (2007) Peasants and Revolution in Rural China: Rural Political Change in the North China Plain and the Yangzi Delta, 1850-1949 (New York: Routledge).

Lu, D. and Neilson, W. (eds.) (2004) China's West Region Development: Domestic Strategies and Global Implications (Singapore: World Scientific).

Lü, X. (2000) Cadres and Corruption: The Organizational Involution of the Chinese Communist Party (Stanford: Stanford University Press).

Lumsden, C. and Wilson, E. (1983) Promethean Fire: Reflections on the Origin of Mind (Cambridge, MA: Harvard University Press).

Ma, D. (2008) "Economic Growth in the Lower Yangzi Region of China in 19111937: A Quantitative and Historical Analysis," The Journal of Economic History, 28(2): 355-392.

Maddison, A. (1998) Chinese Economic Performance in the Long Run (Paris: Organisation for Economic Co-operation and Development, Development Centre Studies).

Maddison, A. (2006) The World Economy: Volumes 1 and 2 (Paris: Organisation for Economic Co-operation and Development, Development Centre Studies).

Maddison, A. (2007) Contours of the World Economy 1-2030 AD: Essays in Macro-Economic History (New York: Oxford University Press).

Mallory, W. (1928) China: Land of Famine (New York: American Geographical Society).

Man-Cheong, I. (2004) The Class of 1761: Examination, State, and Elites in EighteenthCentury China (Stanford: Stanford University Press).

Mann, S. (1987) Local Merchants and the Chinese Bureaucracy, 1750-1950 (Stanford: Stanford University Press).

Marks, R. (1998) Tigers, Rice, Silk, and Silt: Environment and Economy in Late Imperial South China (New York: Cambridge University Press). 
Mitchell, B.R. (2003) International Historical Statistics: Africa, Asia E Oceania (Houndmills, Basingstoke, Hampshire: Palgrave Macmillan).

Miyamoto, M. (2004) “Quantitative Aspects of Tokugawa Economy," in A. Hayami, O. Saitō, and R. P. Toby (eds.) The Economic History of Japan: 1600-1990. Volume 1: The Emergence of Economic Society in Japan, 1600-1859 (New York: Oxford University Press).

Miyazaki, I. (1976) China's Examination Hell: The Civil Service Examinations of Imperial China (New York: John Weatherhill).

Mokyr, J. (2002) The Gifts of Athena: Historical Origins of the Knowledge Economy (Princeton: Princeton University Press).

Morgan, S. (2004) "Economic Growth and the Biological Standard of Living in China, 1880-1930," Economics and Human Biology, 2(2): 197-218.

Mosk, C. (1983) Patriarchy and Fertility: Japan and Sweden, 1880-1960 (New York: Academic Press).

Mosk, C. (1995) Competition and Cooperation in Japanese Labour Markets (Houndmills, Basingstoke, Hampshire: Macmillan Press Ltd).

Mosk, C. (1996) Making Health Work: Human Growth in Modern Japan (Berkeley: University of California Press).

Mosk, C. (2001) Japanese Industrial History: Technology, Urbanization and Economic Growth (Armonk, NY: M.E. Sharpe).

Mosk, C. (2005) Trade and Migration in the Modern World (New York: Routledge).

Mosk, C. (2008) Japanese Economic Development: Markets, Norms, Structures (New York: Routledge).

Mosk, C. and Johannson, S. (1986) "Income and Mortality: Evidence from Modern Japan," Population and Development Review, 12: 415-440.

Müller, D.; Ringer, F. and Simon, B. (1987) The Rise of the Modern Educational System: Structural Change and Social Reproduction, 1870-1920 (New York: Cambridge University Press).

Murphey, R. (1953) Shanghai: Key to Modern China (Cambridge, MA: Harvard University Press).

Myers, R. (1970) The Chinese Peasant Economy: Agricultural Development in Hopei and Shantung, 1890-1949 (Cambridge, MA: Harvard University Press).

Myers, R. (1972) "The Commercialization of Agriculture in Modern China," in W. Willmott (ed.) Economic Organization in Chinese Society (Stanford: Stanford University Press).

Myers, R. (1982) The Japanese Economic Development of Manchuria, 1932-1945 (New York: Garland Publishing, Inc.).

Myers, R. (1989) "Japanese Imperialism in Manchuria: The South Manchurian Railway Company, 1906-1933,” in P. Duus, R. Myers and M. Peattie (eds.) The Japanese Informal Empire in China, 1989-1937 (Princeton: Princeton University Press). 
Nakagane, K. (1989) "Manchuko and Economic Development," in P. Duus, R. Myers and M. Peattie (eds.) The Japanese Informal Empire in China, 1989-1937 (Princeton: Princeton University Press).

Nakajima, T.; Nomura, K. and Matsuura, T. (2004) "Total Factor Productivity Growth: Survey Report” (Tokyo: Asian Productivity Organization).

Ni, S. and Van, P. (2005) "High Corruption Income in Ming and Qing China," Journal of Development Economics 81 (2): 316-336.

Parker, G. (1988) The Military Revolution: Military Innovation and the Rise of the West, 1500-1800 (New York: Cambridge University Press).

Peattie, M. (1989) "Japanese Treaty Port Settlements in China, 1895-1937" in P. Duus, R. Myers, and M. Peattie (eds.) The Japanese Informal Empire in China, 1989-1937 (Princeton: Princeton University Press).

Perkins, D. (1966) Market Control and Planning in Communist China (Cambridge, MA: Harvard University Press).

Perkins, D. (1969) Agricultural Development in China, 1368-1968 (Chicago: Aldine Publishing Company).

Perkins, D. and Rawski, T. G. (2008) "Forecasting China's Economic Growth to 2025," in L. Brandt and T. G. Rawski (eds.) China's Great Economic Transformation (New York: Cambridge University Press).

Perkins, D. and Yusuf, S. (1984) Rural Development in China (Baltimore: The Johns Hopkins University Press for the World Bank).

Pinker, S. (2007) The Language Instinct: How the Mind Creates Language (New York: Harper Perennial Modern Classics, reprint of original 1994 edition).

Pomeranz, K. (2000) The Great Divergence: China, Europe, and the Making of the Modern World Economy (Princeton: Princeton University Press).

Poston, D. and Yaukey, D. (1992) The Population of Modern China (New York: Plenum Press).

Pritchett, L. (1997) “Divergence, Big Time," Journal of Economic Perspectives, 11(1): 3-12.

Rawski, T. G. (1979) Economic Growth and Employment in China (New York: Oxford University Press for the World Bank).

Rawski, T. G. (1989) Economic Growth in Prewar China (Berkeley: University of California Press).

Richerson, R. and R. Boyd (2005) Not by Genes Alone: How Culture Transformed Human Evolution (Chicago: The University of Chicago Press).

Riskin, C. (1975) "Surplus and Stagnation in Modern China," in D. Perkins (ed.) China's Modern Economy in Historical Perspective (Stanford: Stanford University Press).

Ronan, C. (1978) The Shorter Science and Civilisation in China: An Abridgement of Joseph Needham's Original Text. Volume 1 (New York: Cambridge University Press). 
Ronan, C. (1986a) The Shorter Science and Civilisation in China: An Abridgement of Joseph Needham's Original Text. Volume 2 (New York: Cambridge University Press).

Ronan, C. (1986b) The Shorter Science and Civilisation in China: An Abridgement of Joseph Needham's Original Text. Volume 3 (New York: Cambridge University Press).

Ronan, C. (1994) The Shorter Science and Civilisation in China: An Abridgement of Joseph Needham's Original Text. Volume 4 (New York: Cambridge University Press).

Sachs, J. (2005) The End of Poverty: Economic Possibilities for Our Time (New York: The Penguin Press).

Schran, P. (1975) "On the Yenan Origins of Current Economic Policies," in D. Perkins (ed) China's Modern Economy in Historical Perspective (Stanford: Stanford University Press).

Schurmann, F. (1968) Ideology and Organization in Communist China (Berkeley and Los Angeles: University of California Press).

Shen, T.; Habicht, J.-P. and Chang, Y. (1996) "Effect of Economic Reforms on Child Growth in Urban and Rural Areas of China," The New England Journal of Medicine, 335(6): 400-406.

Sheridan, J. (1983) “The Warlord Era: Politics and Militarism Under the Peking Government, 1916-1928," in J. K. Fairbank (ed.) The Cambridge History of China. Volume 12: Republican China, 1912-1949, Part 1 (Cambridge: Cambridge University Press).

Shimokawa, S. (2007) "The Labour Market of Body Weight in China: A Semiparametric Analysis," Applied Economics, 40 (8): 1-20.

Skinner, G. W. (1995) "Marketing and Social Structure in Rural China" (Ann Arbor, MI: Association for Asian Studies).

Strauss, J. (1998) Strong Institutions in Weak Polities: State Building in Republican China (New York: Oxford University Press).

Sun, K. (1969) The Economic Development of Manchuria in the First Half of the Twentieth Century (Cambridge, MA: Harvard University Press).

Tawney, R. (1964) Land and Labor in China (Boston: Beacon Press reprint of original 1932 edition).

Taylor, G. (1980) Japanese Sponsored Regime in North China (New York: Garland Publishing reprint of original 1939 edition).

Thornton, P. (2007) Disciplining the State: Virtue, Violence, and State-Making in Modern China (Cambridge, MA: Harvard University Press).

Umeno, Y. (2008) "From Immigrants to Stayers: Micro-demography of a Historical Lineage in Sichuan, China," The History of the Family, 13(3): 268-282.

United Nations (2004) Statistical Yearbook 2001 (New York: United Nations).

Walker, K. (1965) Planning in Chinese Agriculture: Socialisation and the Private Sector, 1956-1962 (London: Frank Cass \& Co.). 
Wang, F. and Mason, A. (2008) "The Demographic Factor in China's Transition," in L. Brandt and T. G. Rawski (eds.) China's Great Economic Transformation (New York: Cambridge University Press).

Waswo, A. (1977) Japanese Landlords: The Decline of a Rural Elite (Berkeley: University of California Press).

Wilson, E. (1999) Consilience: The Unity of Knowledge (New York: Random House Vintage).

Wittner, D. (2008) Technology and the Culture of Progress in Meiji Japan (New York, Routledge).

World Bank (2002) World Development Indicators 2002 (World Bank: Washington, D.C.).

Wray, W. (1989) "Japan's Big-Three Service Enterprises in China, 1896-1936," in P. Duus, R. Myers, and M. Peattie (eds.) The Japanese Informal Empire in China, 1989-1937 (Princeton: Princeton University Press).

Yamamura, K. (1974) A Study of Samurai Income and Entrepreneurship: Quantitative Analyses of Economic and Social Aspects of the Samurai in Tokugawa and Meiji Japan (Cambridge, MA: Harvard University Press).

Yang, D. (1996) Calamity and Reform in China: State, Rural Society, and Institutional Change since the Great Leap Famine (Stanford: Stanford University Press).

Young, L. (1998) Japan's Total Empire: Manchuria and the Culture of Wartime Imperialism (Berkeley and Los Angeles: University of California Press). 
This page is intentionally left blank 


\section{Index}

Advanced Stage Agricultural Producers Cooperative 182 see also Agricultural Producers Cooperative Agricultural Producers Cooperative (A.P.C.) 151, 181, 182 see also Advanced Stage Agricultural Producers Cooperative

Akamatsu Kaname 97, 133

alliance of convenience 11, 111, 120 , 132, 135, 138, 139, 147, 193

Allied Occupation 138, 143, 156, 159 see also American Occupation

American Occupation 12, 92, 172 see also Allied Occupation

Anglo-Japanese treaty of commerce 123

Aristotle 48

Atahualpa 58

augmentation, labor augmentation, land augmentation 5, 13, 18-21, 23, $93,150,157-159,162,163,168-171$, 180, 181, 184, 185, 192

bakufu 72-75, 78, 79, 94

bakuhan 72, 73, 78, 79

Bank of Japan 81, 84, 85, 157

Beijing 49, 56, 61, 63, 111, 117, 134, 139, 148

Beiyang Army 63, 110

Beiyang Fleet 64

biological standard of living 162

Boxer Rebellion 65 see also Society of Righteous Fists of Harmony

Bretton Woods system 172

British, British Empire 58, 60, 61, 63, 65, 83, 90, 93, 102-104, 109, 117, 121, 129, 135, 136, 138, 165, 178, 194 see also England; United Kingdom

Buddhism, Buddhist 33, 41, 51, 74, 81

Bureau for Recruiting Merchants 64, 85

Cabot 58

Chen Yun 151, 178, 186, 187

Chiang Kai-shek 111, 120, 126, 127, 129, 132, 134, 138, 139

chou (department) 49

Churchill, Winston 137, 138

Cixi 63, 64 see also Dowager Empress

Co-evolution 41, 43

cohong 56 see also hong

collectivization $13,15,30,150,178$, 181-183, 185, 187, 188 see also commune

Comintern 127, 131 see also Communism

command and control 3, 12-15, 20, 22, 23, 25, 105, 126, 132, 133, 139, 144, $153,154,156,166,176,178,180$, 183-189, 193, 194

commune, commune and brigade system $13,14,20,30,151,178$, 180-184, 187, 188 
Communism, Communist, Communist Party (China) 3, 11-13, 15, 23, 29, 30, 41, 103, 105, 106, 108, 111, 113, 115, 120, 121, 127, 129-134, 139, 144, 147-154, 176-178, 180, 182, 183, 187-189, 193

see also Comintern; Marxism-

Leninism

comprador 12, 28, 56, 109, 113, 120 , 132

Confucianism 29, 31, 41, 50, 52, 53, $108,112,113,119,127,139$ see also Neo-Confucianism

conquistador 58

control faction 105, 106

control Yuan 120, 121

Convention of Peking 61

corruption 41, 52-54, 64, 120, 127,

$177,181,189$

Cortéz 58

creative destruction 48

cult of Mao 14, 15, 150, 152, 154, 183 see also Mao

cult of the emperor $11,15,79,81,108$, 144,152 see also emperor

Cultural Revolution 14, 30, 41, 150, 152, 177, 183, 186, 189

daimyō 25, 71-74, 79, 80, 94

demographic transition 35, 36, 97-99, $106,157,183$

Dowager Empress 65 see also Cixi

East India Company 56, 58, 61

Economic Planning Agency 157

Edo (Tokyo) 10, 74, 75, 80, 84, 89, 91, $94,116,128,129$

Eight Banners 49, 55

Einstein 48

electricity; electrification;

hydroelectricity $83,92,94-96$ see also unit drive system

elite $6,17,47,71,89,108,126,143$, $156,177,191$ emperor $11,15,32,50,56,63,73,78$, $79,81,83,105,106,108,111,128$, $132,138,139,144,152$

endaka 172-174

England 57, 58, 60, 61, 71, 72, 102, $111,112,135,153$

Ever Victorious Army 63

Examination, civil examination, military examination $9,27,28$, 31-33, 49-55, 57, 61-63, 65, 66, 71, 109, 115, 120, 192

Examination Yuan 120

extraterritorial rights $10,61,64$

facilitating/coordination approach 23

Fascism 103, 105, 109

fief 76

First National Bank 86

five power constitution 122

Five Year Plan 148, 150, 151, 179

flying geese pattern of trade 153,164

France 56, 57, 61, 64, 65, 71, 72, 104, 112,135

Fujisawa Takeo 146

fukoku kyōhei (enrich the country, strengthen the military) $10,11,25$, 79, 81, 100, 106, 109, 150, 152, 192

Galileo 48

genes 41

gentry $9,12,27-29,31-33,49-55,62$, $65,66,71,78,109,115,147-149$, 192,193

Germany 64, 65, 103, 104, 106, 111, $127,129,134-138$

germ theory of disease 34,99

gold standard 22, 103, 104, 172

gongshi 51

government-sponsored, merchant managed model 62

great divergence 34-36

Greater East Asia Co-Prosperity Sphere 133, 137, see also Japanese Empire, New Order 
Great Leap Forward 14, 20, 150, 151, 177, 182, 183

Guangzhou (Canton) 55

guild 56, 59

Guomindang 29, 110, 111, 113, 120, $121,126,127,129,134$ see also Nationalists

Hanlin Academy 63

Hara Takashi (Kei) 146

Heavenly Kingdom of Great Peace 62 see also Taiping Rebellion

Hitler 104, 127

Holding Company Liquidation Commission 146

Honda Motor Company 146

Honda Soichiro 146

hong 15, 56, 61-65, 85, 102, 134-136, 186-188, 194

Hong Kong 15, 61, 65, 102, 135, 136 , 186-188, 194

Hong Xiuguan 62 see also Taiping Rebellion

hsien (district) 49

Imperial Bank of China 121

Imperial Way 105, 106

import substitution 37,96

industrial enlightenment 48, 60

industrial revolution 47, 58-60, 83

infanticide $37,54,77$

infrastructure $6,7,21-23,25,26,28$, $30,31,35,47,70,72-75,80,83-85$, 89, 92, 93, 95, 97, 101, 106, 109, 114, $115,119,120,148,150,152,154$, $156,170,171,188,191,194$

inorganic economy 33-37, 59, 80, 191, 192

see also organic economy

International Business Machines (IBM) $166,167,173$

iron triangle 157,174

Italy 48, 65, 103, 104, 127, 129, 136, 137

Iwasaki Yatorō 85
Japan Electronics Equipment Corporation (J.E.E.C.) 167

Japanese Army (Japanese Imperial Army) 11, 29, 105, 116, 121, 128, 130, 132-135, 164

Japanese Empire 91, 116, 129, 133 see also Greater East Asia

Co-prosperity Sphere, New

Order

Japanese Navy (Japanese Imperial Navy) 130

Japan National Railroads 93, 94

Japan Socialistic Party 147

Jehol 129, 132, 133

juren 51

just-in-time system 167

kanban ("flag") system 167

Keidanren 26, 157

Kita Ikki 105

Kobe 83, 89, 94, 116

Kong Fuzi (Confucius) 50

Korea 11, 15, 64, 65, 82, 91, 101, 116, 133, 144, 156, 164, 173, 186-188, 194 see also South Korea

Korean War 144

Kwantung Army, Kwangtung Garrison 116, 128, 129,

Labor Adjustment Law 145

Labor Standards Law 145

land reform 91, 92, 105, 115, 144, 145, 148, 152, 182, 193

Land Tax Reform 82, 152

landlord; landlordism; parasitic landlordism $6,12,26,29,30,81$, 83, 85, 91, 92, 111-115, 130, 145, 147-149, 192, 193

League of Nations 103, 138

Liaodong Peninsula 64, 65

Liberal Democratic Party 12, 27, 146, $147,153,157,159$

Li Hongzhang 63, 64, 85

lijin 29, 63, 64, 118

Lin Biao 183

Lincoln, Abraham 110 
Lin Shuangwen 49

Long March 131

\section{Macao 55}

Manchu 28, 49, 62

Manchukō 128, 132, 133, 138

Manchuria 11, 29, 65, 101, 112, 114, $116,117,121,128,129,132,133$, $135,139,147,148,156,193$ see also Manchukō

Mao, Maoist 12, 14, 15, 30, 130, 131, 134, 139, 149-152, 154, 177-184, 186-188, 194

Marco Polo Bridge 134

Market Socialism 187

Marxism-Leninism 108 see also Communism

May Fourth Movement 109, 111, 112, 130

memes 41

Mencius 50, 51

mercantilism ; mercantilist 58-60, 71

merchant-official 54

Ministry of Construction 157

Ministry of Education 81, 145

Ministry of Finance 81, 84, 86

Ministry of International Trade and Industry (M.I.T.I.) 12, 157, 164-167

Miracle Growth 13, 27, 147, 156-162, 164-166, 168-172, 174, 194

Mitsubishi 10, 85, 93, 146, 165, 172, 173

Mitsui 10, 75, 85, 146

Moslem 33, 62

Mukden Incident 128

Mussolini 104

Nagoya 89, 92, 94, 116

Nanjing 61, 63, 113, 117, 120, 121, 127-130, 132-134, 137, 193

Nationalists (Guomindang) 11, 12, 29, 106, 110, 111, 113, 120, 121, 126, 127, 129-134, 136, 139, 147, 193

negative feedback $37-39$

Neo-Confucianism 31, 52 see also Confucianism

New Life Movement 127

New Order 137

see also Japanese Empire; Greater

East Asia Co-Prosperity Sphere

Newtonian 48

Nien Rebellion 62-64, 109

Nikkeiren 26, 157

Northern Expedition 120, 126

one child system 14

open door policy 102, 136

opium; Opium War 56, 60-63, 77, 78, 109, 119

organic economy 33-37, 59, 80, 191, 192

see also inorganic economy

Osaka 73-75, 83-86, 89, 92, 94, 96, 116,118

Pacific War 11, 12, 134, 146, 158, 164, 165 see also World War II

Panthay Rebellion 62

Pao, pao-chia 49, 50

paradigm, paradigm shift 48

path dependence 8,24

Peace of Westphalia 60

Pearl Harbor 106, 134, 136

People's Liberation Army 14, 183, 193

see also Red Army

permanent employment 145, 160

Pizarro 58

Plaza Accord 172

Potsdam Declaration 138, 143

primogeniture 54,55

production function 19

quality control circle 168

Red Army 103, 131, 132

see also People's Liberation Army remittance 20

Renaissance 48, 57, 58

Revive China Society 121 
Roosevelt, Franklin 137, 138

Russia 57, 64, 65, 100, 103, 105, 106, 109,

116, 117, 128, 135-138, 147, 150, 151 see also Soviet Union

Russo-Japanese War 65, 116

Saigō Takamori 82

samurai $9,10,25,31,33-86,146,147$, 192

sankin kotai 74

Satsuma Rebellion 82 see also Western War

self strengthening movement 62,64

Shanghai 9, 28, 29, 63-65, 112,

116-118, 120, 129, 131, 134, 137.

147, 148, 178, 187

Shanghai Steamship Navigation

Company 64

sheng yuan 51

Shibusawa Eiichi 85

shinden 74

Shinto 41, 81, 108

shinzaibatsu 25, 133, 144

see also zaibatsu

shogun 9, 25, 72-74, 78, 79

silver standard 121

Sino-Japanese War 64, 65, 91

Smith, Adam 75

Socialism in One Country 103

Socialist Education Movement 14, 151, 181,184

Society of Righteous Fists of Harmony

65

see also Boxer Rebellion

sociobiology 41, 43

South Korea 15, 173, 186-188, 194 see also Korea

South Manchurian Railroad 65, 101

Soviet Union 12, 111, 113, 128,

133-136, 138, 143, 150-153, 185 see also Russia

Special Economic Zones 15

Spring Offensive 13, 161

Stalin 103, 138, 144

state owned enterprise (S.O.E.) 3, 15,

$30,154,177$
State Planning Commission 179

steam, steam railroad, steamship 34 ,

60, 62, 64, 83, 85, 90, 92-95, 104,

116, 144, 192

stem family system $31,71,76$

Sumitomo 10, 75, 85, 146

Sun Yat-sen 109-111, 120, 134

Supreme Commander of the Allied

Powers 143, 144

surplus labor $3,4,6,12-15,17,20,37$, 43, 113-116, 150, 152, 154, 157, 159, $162,163,178,181,185,187,188$,

$191,192,194$

Taiping Rebellion 62, 63

see also Heavenly Kingdom of Great

Peace; Hong Xiuguan

Taiwan 11, 15, 64, 91, 101, 139, 156, 173, 186-188, 194

Tanaka Kakuei 146, 147

Taoism 51

terakoya 77

Tokyo 10, 74, 80, 84, 89, 91, 94, 116 , 128,129

total factor productivity; total factor productivity growth $13,15,17-19$, 21, 43, 44, 93, 94, 153, 157-159, 163, 165, 167-172, 174, 180, 185, 186

Toyoda Automatic Loom Works 96

Toyota Motor Corporation 167

Toyotomi, Hideyoshi 72, 74

Trade Union Law 145

tragedy of the commons 73

trap, conflict trap, low level equilibrium trap, Malthusian trap, poverty trap 23, 33-39, 59, 87, 95, 100, 106, 139, 189, 191-194

Treaty of Nanjing 61

Treaty of Shimonoseki 64, 109, 118

Treaty of Tianjin 61

Treaty of Versailles 111, 112

tribute grain 52

tribute trade system $60,61,63$

TRON project 173

Truman, Harry 138

twenty-one demands 102, 112, 129 
unconditional surrender 137, 138, 147, 174, 193

unit drive system 95 see also electricity

United Kingdom 65, 102-104, 106, 135-138 see also British; England

United States 12, 35, 60, 61, 65, 77, 80, 83, 96, 101-106, 110, 128, 134, 136-139, 143, 149, 153, 164, 165, 170, 172, 173, 186

University of Tokyo 10, 84

Vespucci, Amerigo 58

Ward, Frederick Thomas 63 warlord 11, 12, 23, 28, 29, 63, 72, 73, 118-121, 127, 128, 130-132

Washington Conference 104

Western War 82, 85 see also Satsuma Rebellion
White Lotus Rebellion 49

work points system 16

World War I 84, 91, 95, 98, 100-104, 109, 111, 112, 116, 117, 146, 192

World War II 6, 12, 20, 92, 98, 138, 148, 149, 164, 187 see also Pacific War

Yangzi River 62, 63, 65, 102, 117, 121, 132, 134, 137, 193

Yokohama 83, 84, 89, 94, 116

Yuan Shikai 63, 65, 102, 110, 111, 126, 127

Xun Zi 50

zaibatsu 10, 12, 25, 84, 85, 94, 96, 102, $104,118,130,133,144,146,147,156$

Zeng Guofan 63

"zero-defects" 167, 168

Zheng Ho 68 